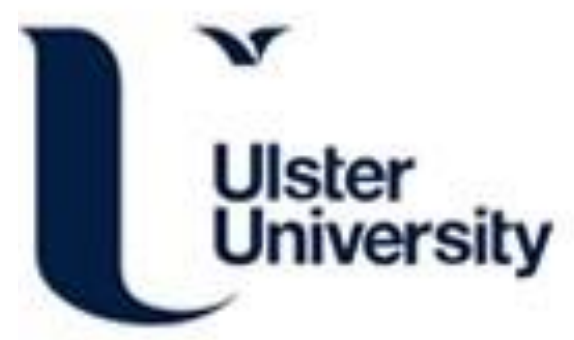

\title{
Non-suicidal self-injury among first-year college students and its association with mental disorders: results from the World Mental Health International College Student (WMH-ICS) initiative
}

WHO World Mental Health International College Student (WMH-ICS) collaborators (2021). Non-suicidal selfinjury among first-year college students and its association with mental disorders: results from the World Mental Health International College Student (WMH-ICS) initiative. Psychological Medicine, 1-12. https://doi.org/10.1017/S0033291721002245

Link to publication record in Ulster University Research Portal

Published in:

Psychological Medicine

Publication Status:

Published online: 18/06/2021

DOI:

10.1017/S0033291721002245

\section{Document Version}

Author Accepted version

\section{General rights}

Copyright for the publications made accessible via Ulster University's Research Portal is retained by the author(s) and / or other copyright owners and it is a condition of accessing these publications that users recognise and abide by the legal requirements associated with these rights.

\section{Take down policy}

The Research Portal is Ulster University's institutional repository that provides access to Ulster's research outputs. Every effort has been made to ensure that content in the Research Portal does not infringe any person's rights, or applicable UK laws. If you discover content in the Research Portal that you believe breaches copyright or violates any law, please contact pure-support@ulster.ac.uk. 
Abstract: 241

Main text: 4,982

Tables and Figures: 5

Non-suicidal self-injury among first-year college students and its association with mental disorders: Results from the World Mental Health International College Student (WMHICS) Initiative

Glenn Kiekens, $\mathrm{PhD}^{1,2,3}$, Penelope Hasking, $\mathrm{PhD}^{4}$, Ronny Bruffaerts, $\mathrm{PhD}^{1,5}$, Jordi Alonso, MD, $\mathrm{PhD}^{6,7,8}$, Randy P. Auerbach, $\mathrm{PhD}^{9}$, Jason Bantjes, $\mathrm{PhD}^{10}$, Corina Benjet, $\mathrm{PhD}^{11}$, Mark Boyes, $\mathrm{PhD}^{4}$, Wai Tat Chiu, $\mathrm{AM}^{12}$, Laurence Claes, $\mathrm{PhD}^{2,13}$, Pim Cuijpers, $\mathrm{PhD}^{14}$, David D. Ebert, $\mathrm{PhD}^{15}$, Arthur Mak, MBChB, FRCPsych ${ }^{16}$, Philippe Mortier, MD, $\mathrm{PhD}^{6,7}$, Siobhan O’Neill, $\mathrm{PhD}^{17}$, Nancy A. Sampson, BA ${ }^{12}$, Dan J. Stein, FRCPC, $\mathrm{PhD}^{18}$, Gemma Vilagut, $\mathrm{PhD}^{6,7}$, Matthew K. Nock, $\mathrm{PhD}^{19}$, Ronald C. Kessler, $\mathrm{PhD}^{12}$ and on behalf of the WHO World Mental Health International college student (WMH-ICS) collaborators.

${ }^{1}$ Center for Public Health Psychiatry, KU Leuven, Belgium, ${ }^{2}$ Faculty of Psychology and Educational Sciences, KU Leuven, Leuven, Belgium, ${ }^{3}$ Center for Contextual Psychiatry, KU Leuven, Leuven, Belgium, ${ }^{4}$ School of Population Health, Curtin University, Perth, Australia, ${ }^{5}$ Institute for Social Research, Population Studies Center, University of Michigan, Ann Arbor, Michigan, USA, ${ }^{6}$ Health Services Research Unit, IMIM (Hospital del Mar Medical Research Institute), Barcelona, Spain, ${ }^{7}$ CIBER en Epidemiología y Salud Pública, Madrid, Spain, ${ }^{8}$ Pompeu Fabra University, Barcelona, Spain, ${ }^{9}$ Department of Psychiatry, Columbia University, New York, USA, ${ }^{10}$ Institute for Life Course Health Research, Department of Global Health, Faculty of Medicine and Health Sciences Stellenbosch University, South Africa, ${ }^{11}$ Department of Epidemiologic and Psychosocial Research, National Institute of Psychiatry Ramón de la Fuente Muñiz, Mexico City, Mexico, ${ }^{12}$ Department of Health Care Policy, Harvard Medical School, Boston, MA, USA, ${ }^{13}$ Faculty of Medicine and Health Sciences (CAPRI), University of Antwerp, Antwerp, Belgium, ${ }^{14}$ Department of Clinical, Neuro and Developmental Psychology, Amsterdam 
Public Health Research Institute, Vrije Universiteit Amsterdam, Amsterdam, the Netherlands,

${ }^{15}$ Department for Sport and Health Sciences, Chair for Psychology \& Digital Mental Health Care, Technical University Munich, Germany, ${ }^{16}$ Department of Psychiatry, The Chinese University of Hong Kong, Hong Kong, Hong Kong SAR, ${ }^{17}$ School of Biomedical Sciences, Ulster University, Derry-Londonderry, Northern Ireland, ${ }^{18}$ Department of Psychiatry and Mental Health and South African Medical Council Research Unit on Risk and Resilience in Mental Disorders, University of Cape Town and Groote Schuur Hospital, Cape Town, South Africa, ${ }^{19}$ Department of Psychology, Harvard University, Cambridge, MA, USA.

\section{Funding Acknowledgments}

Funding to support this project was received from the National Institute of Mental Health (NIMH) R56MH109566 (RPA), and the content is solely the responsibility of the authors and does not necessarily represent the official views of the National Institutes of Health or NIMH; Flemish Fund for Scientific Research (11N0514N/11N0516N and 1114717N/1114719N) (PM, GK), the King Baudouin Foundation (2014-J2140150-102905) (RB), and Eli Lilly (IIT-H6U-BX-I002) (RB, PM); BARMER, a health care insurance company, for project StudiCare (DDE); ZonMw (Netherlands Organisation for Health Research and Development; grant number 636110005) and the PFGV (PFGV; Protestants Fonds voor de Geestelijke Volksgezondheid) in support of the student survey project (PC); South African Medical Research Council (Mid-Career Scientist Programme awarded to Jason Bantjes); Consejo Nacional de Ciencia y Tecnología (CONACyT:

CB-2016-01-28554) (CB); Fondo de Investigación Sanitaria, Instituto de Salud Carlos III FEDER (PI13/00343), ISCIII (Río Hortega, CM14/00125), ISCIII (Sara Borrell, CD12/00440); European Union Regional Development Fund (ERDF) EU Sustainable Competitiveness Programme for Northern Ireland, Northern Ireland Public Health Agency (HSC R\&D), and Ulster University; Ministerio de Sanidad, Servicios Sociales e Igualdad, PNSD (Exp. 2015I015); DIUE Generalitat de Catalunya (2017 SGR 452), FPU (FPU15/05728) (JA). In Australia the World 
Mental Health International College Student project is supported by Suicide Prevention Australia (PH) and the National Health and Medical Research Council (NHMRC; MB). Philippe Mortier has a Sara Borrell research contract awarded by the Instituto de Salud Carlos IIII (SCIII CD18/00049). The World Mental Health International College Student project is carried out as part of the WHO World Mental Health (WMH) Survey Initiative. The WMH survey is supported by the National Institute of Mental Health NIMH R01MH070884, the John D. and Catherine T. MacArthur Foundation, the Pfizer Foundation, the US Public Health Service (R13-MH066849, R01-MH069864, and R01 DA016558), the Fogarty International Center (FIRCA R03TW006481), the Pan American Health Organization, Eli Lilly and Company, Ortho-McNeil Pharmaceutical, GlaxoSmithKline, and Bristol-Myers Squibb. The World Mental Health International College Student (WMH-ICS) initiative is carried out as part of the WHO World Mental Health (WMH) Survey Initiative. A complete list of all WMH-ICS publications can be found at: http://www.hcp.med.harvard.edu/wmh/college_student_survey.php

\section{Corresponding author:}

Glenn Kiekens, PhD.

Tiensestraat 102, box 3720, 3000 Leuven, Belgium.

Tel:+3216372852

E-mail: Glenn.Kiekens@kuleuven.be 


\begin{abstract}
Background: Although non-suicidal self-injury (NSSI) is an issue of major concern to colleges worldwide, we lack detailed information about the epidemiology of NSSI among college students. This study's objectives were to present the first cross-national data on the prevalence of NSSI and NSSI disorder among first-year college students and its association with mental disorders.

Methods: Data come from a survey of the entering class in 24 colleges across nine countries participating in the World Mental Health International College Student (WMH-ICS) initiative assessed in web-based self-report surveys (20,842 first-year students). Using retrospective age-ofonset reports, we investigated time-ordered associations between NSSI and DSM-IV mood (major depressive and bipolar disorder), anxiety (generalized anxiety and panic disorder), and substance use disorders (alcohol and drug use disorder).

Results: NSSI lifetime and 12 -month prevalence were $17.7 \%$ and $8.4 \%$. A positive screen of 12 month DSM-5 NSSI disorder was 2.3\%. Of those with lifetime NSSI, 59.6\% met the criteria for at least one mental disorder. Temporally primary lifetime mental disorders predicted subsequent onset of NSSI (Median OR=2.4), but these primary lifetime disorders did not consistently predict 12-month NSSI among respondents with lifetime NSSI. Conversely, even after controlling for preexisting mental disorders, NSSI consistently predicted later onset of mental disorders (Median $\mathrm{OR}=1.8$ ) as well as 12-month persistence of mental disorders among students with a generalized anxiety disorder $(\mathrm{OR}=1.6)$ and bipolar disorder $(\mathrm{OR}=4.6)$.
\end{abstract}

Conclusions: NSSI is common among first-year college students and is a behavioral marker of various common mental disorders.

Keywords: non-suicidal self-injury, mental disorders, adolescence, emerging adulthood, college students 


\section{Introduction}

Non-suicidal self-injury, defined as the direct and deliberate damage to one's body tissue for reasons other than to end one's life (International Society for the Study of Self-Injury, 2018), is a significant public health issue among young people worldwide. The onset of NSSI peaks in adolescence around the age of 14-15 (Gandhi et al., 2018), with pooled lifetime prevalence rates estimated in the $15.1 \%$ to $22.7 \%$ range among 12 - to 18 -year olds (Gillies et al., 2018). While NSSI is often episodic, the 12-month prevalence is estimated to be $2-14 \%$ among emerging adults (Benjet et al., 2017; Serras, Saules, Cranford, \& Eisenberg, 2010; Whitlock et al., 2011; Wilcox et al., 2012). For approximately $70 \%$ of adolescents in high-income countries (BLS, 2017; Roser \& Ortiz-Ospina, 2013), the transition to emerging adulthood (18-29 years) coincides with college entrance. The college years constitute a unique period for personal growth characterized by exploration and opportunities in identity development, interpersonal and romantic relationships, and excitement about future occupational prospects (Arnett, 2015, 2016; Magolda \& Taylor, 2015; Shulman \& Connolly, 2013). However, this is also a period of heightened instability and uncertainty. Academic pressure, identity confusion, relationship concerns, financial hardship, and uncertainty about future employment can all combine to make this a stressful time (American College Health Association, 2018; Arnett, Žukauskienè, \& Sugimura, 2016; Cvetkoski, Reavley, \& Jorm, 2012, Karyotaki et al., 2020). Research shows that college students are at risk for a broad range of mental health problems (Bruffaerts et al., 2018; Hunt \& Eisenberg, 2010; Mortier et al., 2017), with $20-30 \%$ meeting criteria for at least one 12-month mental disorder (Auerbach et al., 2016, 2018). However, few students are willing to seek help (Ebert et al., 2019), and many do not find their way to treatment (Auerbach et al., 2016; Bruffaerts et al., 2019).

Accordingly, students may use emotion-regulating behaviors like self-injury to cope with college-related stressful experiences (Hamza, Goldstein, Health, \& Ewing 2021). Researchers have observed that $25-63 \%$ of those with adolescent-onset NSSI continue to self-injure (Glenn \& 
Klonsky, 2011; Hamza \& Willoughby, 2014), and 7\% begin repetitive NSSI during the college years (Kiekens et al., 2019). Recent studies also suggest that rates of NSSI among college students have increased over the past decade (Duffy, Twenge, \& Joiner, 2019; Wester, Trepal, \& King, 2018). However, we lack a representative cross-national reference regarding the prevalence of NSSI among college students. Prior studies have found that rates of NSSI varied from 5\% to 55\% in college samples, relying primarily on non-representative samples of psychology students (Swannell, Martin, Page, Hasking, \& St John, 2014). A better understanding of the prevalence and course of NSSI should be considered a necessary first step in screening at-risk students and evaluating new interventions (Glenn, Jaroszewski, Milner, Kearns, \& Nock, 2015). Relative to students who do not self-injure, emerging evidence suggests that students who engage in NSSI may be more likely to report academic failure (Kiekens et al., 2016), experience greater stigmatization (Burke, Piccirillo, Moore-Berg, Alloy, \& Heimberg, 2019), and exhibit higher rates of suicidal thoughts and behaviors (Hamza \& Willoughby, 2016). Together, these findings underscore the clinical significance of NSSI among college students.

Numerous studies have highlighted the strong association between NSSI and the presence of a mental disorder (Kiekens et al., 2018; Taliaferro \& Muehlenkamp, 2015). Although historically considered a symptom of mental illness, NSSI is now recognized as a transdiagnostic behavior that occurs in a variety of diagnostic contexts and warrants research in its own right (Selby, Kranzler, Fehling, \& Panza, 2015). The American Psychiatric Association formally emphasized this viewpoint in 2013 with the inclusion of NSSI as a "condition requiring further study" in section III of the Diagnostic and Statistical Manual of Mental Disorders, Fifth Edition (DSM-5; APA, 2013) However, the high co-occurrence between NSSI and mental disorders raises several critical questions regarding the nature of this association, particularly whether NSSI functions as a correlate, risk factor, or outcome of mental illness. Prospective studies show that mental disorders predict the onset of NSSI (Fox et al., 2015; Kiekens et al., 2019), but more work is needed to tease apart whether specific mental disorders are predictors of NSSI onset and course. 
Conversely, there is emerging evidence that the presence of NSSI may be associated with an increased risk of newly emerging mental disorders (Daukantaitė et al., 2020; Wilkinson, Qiu, Neufeld, Jones, \& Goodyer, 2018). However, it remains unclear whether NSSI uniquely predicts the onset and course of specific mental disorders. Clarifying the developmental directionality between NSSI and mental disorders will be essential for developing appropriate screening, prevention, and mental disorders treatment.

In the present study, we investigate: (1) the prevalence of NSSI in a cross-national sample of college students, and (2) temporal associations between onset and recency of NSSI and several common DSM-IV disorders. Data were obtained from a census of the entering class in 24 colleges across nine countries participating in the WHO World Mental Health International College Student Initiative (WMH-ICS). The WMH-ICS is a coordinated series of ongoing epidemiological surveys of common mental disorders among college students, along with cost-effective, evidencebased prevention and clinical interventions using precision medicine procedures (Cuijpers et al., 2019). Given that the WMH-ICS gathers the age-of-onset of the disorders assessed, we were able to investigate reciprocal time-lagged associations based on retrospective reports between NSSI and DSM-IV mood (major depressive and bipolar disorder), anxiety (generalized anxiety and panic disorder), and substance use disorders (alcohol and drug use disorder).

\section{Method}

\section{Sample}

The first wave of WMH-ICS surveys was administered to first-year students in 24 colleges and universities (henceforth referred to as "colleges") in nine middle- to high-income countries (Australia, Belgium, Germany, Hong Kong, Mexico, Northern Ireland, South Africa, Spain, and the United States). Web-based self-report questionnaires were administered to all first-year students in each college (eight private and 16 public) across these countries between October 2014 and February 2018. In addition to earlier WMH-ICS reports (Auerbach et al., 2018; Mortier et al., 
2018a), the current sample includes five new colleges, one additional country (Hong Kong), and 6,998 additional students. A total of 21,369 questionnaires were completed, with sample sizes ranging from 208 in Hong Kong to 8,076 in Mexico. The weighted (by achieved sample size) mean response rate across surveys was $45.6 \%$. Supplementary Table 1 presents an overview of the sample design in each country. The sample for the analyses reported here is restricted to students identifying as male or female who were full-time students $(n=20,842)$. Students excluded from analyses ( $n=527)$ were: (a) those who did not identify as male or female ( $n=79)$; (b) those who reported not being a full-time student $(n=413)$; and (c) those with missing information on gender or student status $(n=39)$.

\section{Procedure}

All first-year students were invited to participate in a web-based self-report survey. The mode of contact varied across colleges, with the survey incorporated into a routine health evaluation in some colleges, as part of the registration process in others, and as a stand-alone survey advertised via student e-mail addresses in still others. In cases other than in Mexico, all first-year students were invited to participate, and initial non-respondents were re-contacted through a series of personalized reminder e-mails containing unique electronic links to the survey. In Mexico, students were invited to participate in conjunction with mandatory activities, which varied between colleges (e.g., student health evaluations, tutoring sessions), with time set aside for completing the survey during these sessions. In Hong Kong, all respondents who completed the survey were given a store credit coupon as an incentive. In other countries, conditional incentives were offered in the final stages of refusal conversion (e.g., movie passes). In Spain, an "end-game strategy" was used in which a random sample of non-respondents was offered an incentive for participation. Respondents to these end-game surveys were given a weight equal to $1 / \mathrm{p}$, where $\mathrm{p}$ represents the proportion of non-respondents at the end of the standard recruitment period that was included in the end-game to adjust for the under-sampling of difficult-to-recruit students. Informed 
consent was obtained from all students before administering the questionnaires, and institutional review boards approved the study procedures of all participating colleges.

\section{Measures}

Non-suicidal self-injury. The self-report version of the Self-Injurious Thoughts and Behaviors Interview (SITBI) was used to assess lifetime and 12-month NSSI (Nock, Holmberg, Photos, \& Michel, 2007). In Australia and Belgium, lifetime NSSI was assessed with a checklist from the SITBI that asks respondents to indicate each NSSI behavior (e.g., cutting, hitting, burning) they ever engaged in to hurt themselves on purpose, without wanting to die. In all other countries, lifetime NSSI was assessed with a single item taken from the SITBI: "Did you ever do something to hurt yourself on purpose, without wanting to die (e.g., cutting yourself, hitting yourself, or burning yourself)?". Follow-up questions assessed the age-of-onset and frequency of NSSI. Consistent with the proposed DSM-5 frequency criterion (i.e., self-injury on five or more days in the past year), students screened positively for 12-month NSSI disorder if they reported at least five instances of NSSI in the past year (using available past year response categories this was operationalized as $\geq 5$ acts in Australia and Belgium and $>5$ acts in other countries). Prior research has shown that the SITBI has good construct validity $(\kappa=0.74-1.0)$ and excellent testretest reliability for the presence of NSSI ( $\kappa=1.0$; Nock et al., 2007). The self-report format has also demonstrated strong alternate-forms reliability $(\kappa=0.84)$ and excellent test-retest reliability $(\kappa=0.94-1.0)$ and external validity $(\kappa=1.0$; Fox et al., 2020; Latimer, Meade, \& Tennant, 2013).

Socio-demographic and college-related variables. Gender was assessed by asking respondents whether they identified themselves as male, female, transgender (male-to-female, female-to-male), or “other." Respondent age at the survey was categorized as 18 years, 19 years, 20 or more years old. Parental educational level was assessed for father and mother (none, elementary, secondary, some post-secondary, college graduate, doctoral degree), and was categorized into low (secondary school or less), medium (some post-secondary education), and high (college graduate or more), based on the highest-of-both parents' educational level. 
Respondents were also asked where they ranked academically (from top 5\% to bottom 10\%) compared with other students at the time of their high school graduation and was categorized into top $10 \%$, top $30-10 \%$, and bottom $70 \%$. Parental marital status was dichotomized into "parents not married or at least one parent deceased" versus "parents married and both alive". The religious background was categorized as “Christian", "other religion", and "no religion”. Similar to previous WMH-ICS reports (Auerbach et al., 2018; Mortier et al., 2018), sexual orientation was classified as: heterosexual with no same-sex attraction, heterosexual with same-sex attraction, non-heterosexual without same-sex sexual intercourse, and non-heterosexual with same-sex sexual intercourse.

Mental disorders. The self-administered questionnaire included short validated self-report screening scales for six common DSM-IV mood (major depressive and bipolar disorder), anxiety (generalized anxiety and panic disorder), and substance use disorders (alcohol abuse or dependence [AUD], drug abuse or dependence, involving either cannabis, cocaine, any other street drug, or a prescription drug either used without a prescription or used more than prescribed to get high, buzzed, or numbed out). The assessment of these mental disorders, except for AUD, was based on the Composite International Diagnostic Interview Screening Scales (CIDI-SC; Kessler \& Ustun, 2004). The CIDI-SC was developed by the WHO to gain reliable estimates of DSM-IV mental disorder diagnoses, with clinical reappraisal studies generally indicating good concordance between CIDI-SC and independent clinical diagnoses based on structured clinical interviews, with an area under the curve (AUC) in the range of 0.70-0.78 (Kessler, Calabrese, et al., 2013; Kessler, Santiago, et al., 2013). An initial validation study among Spanish college students confirmed that all diagnostic outcomes show good AUCs $(>0.7)$, except panic disorder, which demonstrates fair concordance with clinical diagnosis (AUC $=0.6$; Ballester et al., 2019). Assessment of AUD was based on the Alcohol Use Disorders Identification Test (AUDIT; Saunders, Aasland, Babor, de la Fuente, \& Grant, 1993). The version of AUDIT that we used (Babor, Higgings-Biddle, Saunders, \& Monteiro, 2001), which defines alcohol use disorder as either a total score of $16+$ or a score 8- 
15 with 4+ on the AUDIT dependence questions, has been shown to have good concordance with clinical diagnoses (AUCs in the 0.78-0.91 range; Reinert \& Allen, 2002). Additional items from the CIDI were used to assess age-of-onset of each disorder (Kessler \& Ustun, 2004).

\section{Statistical Analysis}

Data were weighted to adjust for differences between survey respondents and nonrespondents on whatever socio-demographic information made available by college officials using post-stratification weights. This always included gender and age, but additional information was used when available (e.g., socio-economic status, parental educational level). Multiple imputation (MI) by chained equations was used to adjust for item-missing data, random internal sampling of survey sections in some countries to reduce survey length, and missing data due to skip logic errors that occurred in a few surveys (van Buuren, 2007). All estimates were pooled across 20 multiple imputed datasets using Rubin's rules (Rubin, 1987), with associated MI-adjusted standard errors obtained through the Taylor series linearization method.

A series of models was estimated to understand the associations between NSSI and mental disorders. First, discrete-time survival models, with person-year as the unit of analysis and a logistic link function (Efron, 1988,) were used to investigate time-lagged associations between mental disorders/NSSI and the subsequent onset of NSSI/mental disorders, respectively. A personyear data set was created such that each year in the life of each respondent (up to and including the age at onset of the outcome disorder or age at the survey, whichever came first) was treated as a separate observational record. Person-years began at age 4, the youngest age evaluated for possible disorder and NSSI onset (Gandhi et al., 2018; Green et al., 2010). Predictor variables were considered time-varying, with predictors lagged relative to the outcome. We estimated models that examined bivariate associations between NSSI and only one common mental disorder at a time (with adjustment for country, gender, age, education, parental marital status, religion, sexual orientation, and person-year) as well as multivariate models that included information on all temporally primary mental disorders. To better understand the unique associations between 
type of mental disorders, number of mental disorders, and NSSI, we considered two types of multivariate models: one that included all types of mental disorders simultaneously (multivariate additive), and one that included type and number of mental disorders experienced by each respondent as dummy variables (multivariate interactive).

Second, we investigated the associations between primary mental disorders/NSSI and recency of NSSI/mental disorders, respectively, using logistic regression models with person as the unit of analysis. Recency was defined as the ratio of 12-month (i.e., presence in the year before the survey) to lifetime prevalence. A predictor was considered present in these models only if the predictor emerged before the outcome or when the outcome did not (yet) occur. We again considered bivariate and multivariate models that were adjusted for socio-demographic variables and included dummy variables for age-of-onset, time since onset, and high-school ranking. In light of the NSSI disorder included in DSM-5 (APA, 2013), we additionally investigated associations between primary mental disorders and meeting the diagnostic frequency criterion (i.e., at least five instances of NSSI in the past year) among those reporting 12-month NSSI. This gives us an indication of the value of mental disorders in determining clinically severity among those reporting 12-month NSSI at college entrance. Coefficients in all these models were exponentiated to create odds ratios (ORs) with 95\% confidence intervals.

All results were pooled across countries using fixed-effects modeling (FEM) by including dummy control variables for country membership. Due to considerable variation in country sample sizes and survey procedures, no attempt was made to explore between-country variation in associations. Given that our focus is on pooled within-group associations between individual-level predictors and dependent variables rather than geographic variation in mean associations, we chose FEM instead of multilevel modeling to account for the nested structure of the data. FEM is preferable in this particular situation because it does not have the restrictive, and in our case, inappropriate, assumption that the aggregate units (i.e., countries and colleges within countries) 
represent random samples from the population of all such units (Goldstein, 2011). All significance tests were evaluated using $\alpha=0.05$, two-sided test. Analyses were conducted with SAS version 9.4.

\section{Results}

\section{Prevalence of NSSI among first-year college students}

The lifetime and 12-month prevalence of NSSI was $17.7 \%$ (SE=0.3; IQR between countries $=14.3-19.6 \%)$ and $8.4 \%(\mathrm{SE}=0.2$; IQR between countries $=4.8-10.3 \%)$, respectively. Of those reporting 12-month NSSI, 28.0\% (SE=1.1) screened positively for 12-month DSM-5 NSSI disorder. This corresponds to $2.3 \%$ ( $\mathrm{SE}=0.1$; IQR between countries=1.0-3.1\%) of the entire sample. The median age-of-onset of NSSI was 13.7 years $(\mathrm{IQR}=11.7-15.4)$. Figure 1 displays the hazard function and the projected cumulative lifetime probability curve for the age-of-onset of NSSI up to the age of 25 years. As shown, the probability of NSSI is low in childhood, starts to increase in early-adolescence, peaks in mid-adolescence between 15-16 years, and then declines again across the age range 17 to 22 years. The hazard function increases again between 23-25 years, but this finding should be interpreted with caution in this first-year college sample. Among respondents who began NSSI more than one year ago, the recency (12-month-to-lifetime) ratio for NSSI was $44 \%(\mathrm{SE}=0.9)$.

When considering socio-demographic correlates of NSSI (a detailed presentation of these analyses can be found in Supplementary Table 2), there are three notable findings. First, compared to male students, female students had slightly higher odds for the onset of NSSI (OR=1.6, $95 \% \mathrm{CI}=1.4-1.7$ ), but a significantly lower probability of 12-month NSSI among those reporting lifetime NSSI $(\mathrm{OR}=0.8,95 \% \mathrm{CI}=0.7-1.0)$. Second, recency of NSSI was positively associated with an early-onset ( 11 or younger versus $15-17$ years; $O R=1 / 0.6=1.7$ ) and onset in the year before college $(\mathrm{OR}=5.0 ; 95 \% \mathrm{CI}=3.2-7.8)$. Third, non-heterosexual orientation consistently predicted onset, recency, and clinical severity of NSSI (ORs in the 1.6-2.9 range).

[Include Figure 1 about here] 


\section{Co-occurrence and temporal priorities between NSSI and DSM-IV mental disorders}

We first examined the prevalence of lifetime mental disorders among respondents with and without a history of NSSI regardless of the temporal order (Table 1). Respondents reporting NSSI had significantly higher rates $(7.3-35.2 \% ; 59.6 \%$ any disorder) than those with no history of NSSI $(2.3-11.6 \% ; 25.0 \%$ any disorder) for all six common disorders (ORs in the 1.7-5.0 range). We then considered the temporal sequence between the onset of NSSI and the onset of each separate mental disorder within the subset of respondents who reported both NSSI and the mental disorder. Table 1 summarizes the proportion of respondents with (1) NSSI onset before particular mental disorder onset, (2) NSSI onset in the same year as the mental disorder, and (3) NSSI onset after the mental disorder onset. Goodness-of-fit tests revealed that NSSI occurred more often before than after panic disorder, bipolar disorder, alcohol use disorder, and drug use disorder. In contrast, major depressive disorder occurred more often before (44.1\%) than after NSSI onset $(32.7 \%$; $\left.X^{2}=22.5, p<.001\right)$, while there was no difference in temporal sequence for generalized anxiety disorder.

[Include Table 1 about here]

\section{Associations between temporally primary DSM-IV mental disorders and subsequent onset, recency, and severity of NSSI}

We then examined the associations between mental disorders and subsequent onset, recency, and severity of NSSI taking into consideration differences in the age at onset distributions of the different disorders in relation to the age at onset distribution of NSSI (Table 2). Bivariate survival models revealed that each of the examined disorders was significantly associated with the subsequent onset of NSSI, with ORs ranging from 1.6 for alcohol use disorder to 3.3 for major depressive disorder (Median $\mathrm{OR}=2.8$ ). Four out of six mental disorders were also significant, although weaker, predictors of recency (Median $\mathrm{OR}=1.5$ ) and meeting the $5+$ diagnostic frequency criterion (Median $\mathrm{OR}=1.8$ ). Subsequently, we evaluated the association between the number of 
mental disorders and onset, recency, and severity of NSSI by estimating models in which the only substantive predictors were dummy variables for the number of primary mental disorders (Table 2). These models revealed a dose-response relationship between the number of disorders and each of the NSSI outcomes. For NSSI onset, ORs increased from 2.7 for those with one primary preceding disorder (relative to those with zero disorders) to 4.2 for those with exactly two and three or more preceding mental disorders. As was generally the case for the associations between type of disorder and recency and severity of NSSI, the ORs for the number of disorders become smaller in models that predict 12-month NSSI among those reporting lifetime NSSI (ORs in the 1.3-3.0 range) and meeting the 5+ diagnostic frequency criterion among those reporting 12-month NSSI (ORs in the 1.5-2.3 range), respectively.

[Include Table 2 about here]

Model coefficients in the multivariate models show that the strongest effects are found for the prediction of NSSI onset in the multivariate interactive model (ORs in the 1.6-3.4 range). The odds ratios associated with the number of disorders in this model were significantly lower than 1.0 and became smaller as the number of disorders becomes larger, indicating a sub-additive interaction whereby the relative odds of NSSI onset increases at a decreasing rate with the number of temporally primary disorders. A similar pattern of results was not observed when predicting recency and severity of NSSI, indicating additive effects for type of mental disorders. However, the association with most disorders became non-significant in these multivariate models, except for the association between panic disorder and 12-month NSSI among the sample with lifetime NSSI $(\mathrm{OR}=2.3)$ and major depressive disorder and meeting the $5+$ diagnostic frequency criterion among those reporting 12-month NSSI (OR=1.4).

[Include Table 3 about here] 
Associations between temporally primary NSSI and subsequent onset and recency of DSM-

\section{IV mental disorders}

We also examined the associations between NSSI and the subsequent onset and recency of particular mental disorders (Table 4). NSSI was associated with the subsequent onset of all assessed mental disorders (Median $\mathrm{OR}=2.3$ ). Controlling for pre-existing mental disorders, these associations became weaker but remained significant, with ORs ranging from 1.3 for major depressive disorder to 2.0 for bipolar disorder (Median $\mathrm{OR}=1.8$ ). Bivariate- and multivariate models revealed that NSSI was also associated with elevated odds of 12-month bipolar disorder (ORs in the 4.6-5.0 range) and generalized anxiety disorder (ORs in the 1.6-1.7 range) among college students who met lifetime criteria for these disorders.

[Include Table 4 about here]

\section{Discussion}

This study's objective was to estimate the prevalence and examine basic retrospectively reported time-lagged associations between the onset and recency of NSSI and common DSM-IV disorders among first-year college students. Several noteworthy findings were revealed. First, consistent with meta-analytic findings in adolescent samples, we found a pooled cross-national lifetime NSSI prevalence of $17.7 \%$ with a typical onset in mid-adolescence (Gillies et al., 2018; Swannell et al., 2014). In addition, we observed that for $44 \%$ of students, NSSI persisted into the first year of college, approximately one-quarter of whom met the 5+ diagnostic frequency criterion proposed in the DSM-5. We also replicated prior studies in finding that socio-demographic correlates of NSSI are generally weak (Kiekens et al., 2019), indicating that NSSI is widely distributed across all segments of the incoming college student population. Being female was associated with a slightly increased risk of lifetime NSSI (Bresin \& Schoenleber, 2015), identifying as non-heterosexual with a moderately increased risk of lifetime NSSI (Batejan, Jarvi, $\&$ Swenson, 2015), as well as recency and severity of NSSI at college entrance. 
Second, our retrospectively-reported time-lagged analyses confirm that the presence of a lifetime mental disorder is related to the subsequent onset of NSSI (Fox et al., 2015; Kiekens et al., 2019). The relatively consistent increased odds of NSSI onset associated with temporally primary disorders indicate that a wide range of mental disorders predict subsequent NSSI, although mood disorders were a somewhat stronger predictor than the other disorders considered here. These findings are consistent with a vulnerability conceptualization in which distress, and impairment associated with mental disorders (Alonso et al., 2018), signal increased susceptibility for self-injury. Extending earlier work, we also observed a dose-response relationship between the number of temporally primary mental disorders and subsequent onset of NSSI, with the increased odds of NSSI decreasing as the number of prior disorders increases. From a developmental psychopathology perspective (Shahar \& Henrich, 2019), these findings support a dualvulnerability pattern ${ }^{1}$ whereby a mental disorder's incremental utility is most potent for those without mental disorders and has an upper limit for those with comorbid disorders. One potential explanation for this ceiling effect may be shared etiological pathways through which disorders govern risk for onset of NSSI (Bentley, Cassiello-Robbins, Vittorio, Sauer-Zavala, \& Barlow, 2015). Additional NSSI-specific risk factors, such as NSSI-related cognitions (Hasking, Whitlock, Voon, \& Rose, 2017) and self-criticism (Hooley \& Franklin, 2017), may need to be taken into account to determine who develops an onset of NSSI. Future studies that illuminate the psychological mechanisms leading to NSSI are needed to elucidate the pathways through which earlier mental disorders are associated with risk of NSSI. Of note, though, mental disorders appear to be less strongly predictive of the course of NSSI once initiated. This finding highlights the need to understand better what other (i.e., non-diagnostic) factors predict ongoing self-injury among college students. Ecological momentary assessment studies that investigate such relationships with

\footnotetext{
${ }^{1}$ We thank an anonymous reviewer for bringing this to our attention.
} 
greater temporal specificity may provide a unique opportunity to clarify factors that govern more proximal risk of NSSI (Burke et al., 2021; Hepp et al., 2020; Kiekens et al., 2020, 2021).

Third, our retrospective results suggest that NSSI often occurs before the onset of the mental disorders considered here (32.7-69.8\%) and is associated with the subsequent onset of each of these disorders. These time-lagged associations remained when controlling for other temporally primary mental disorders. Furthermore, we also observed that prior NSSI is associated with recency of generalized anxiety disorder and bipolar disorder among students with a lifetime history. There are two explanations for these findings, which cannot be ruled out based on the present study. First, NSSI may precede the onset of a mental disorder and be a behavioral marker of an emerging mental disorder and its course (i.e., course pattern explanation; Shahar et al., 2006). This might be because it is an indicator of more severe temporally primary disorders, and this severity - which we did not assess - is the more proximal predictor of secondary disorders. Second, the presence of NSSI may increase the susceptibility for mental disorders (i.e., cause pattern explanation). Emerging evidence suggests that engagement in NSSI brings not only shortterm relief but may also lead to negative psychosocial outcomes, including stigma due to scarring (Burke et al., 2019; Staniland, Hasking, Boyes, \& Lewis, 2020), interpersonal stressors about selfinjury (Burke, Hamilton, Abramson, \& Alloy, 2015; Waals et al., 2018), and impaired psychological functioning (Buelens, Luyckx, Gandhi, Kiekens, \& Claes, 2019; Robinson et al., 2018). Taken together, the present findings add to a growing body of evidence that NSSI is important in its own right and underscore the need to obtain better insight into the developmental consequences of engaging in NSSI and the potential mediating mechanisms underlying the timeorder associations with mental disorders.

While this study includes a large sample across a range of countries, a number of significant limitations should be kept in mind when interpreting these results. First, the crossnational prevalence estimates are based on a convenience sample of colleges, potentially limiting the generalizability of results. Relatedly, response rates were not optimal in all countries. 
Although analyses were weighted, it has recently been shown that there is a risk of overestimating prevalence rates in samples with lower response rates to self-report surveys (Mortier et al., 2018b). Second, the retrospective self-report nature of the data can introduce underreporting or biased recall about the timing of onset. However, given the age of participants in this student sample, recall bias is likely minimized. Third, we used screening scales instead of full diagnostic interviews to assess risk for mental disorders; hence, these prevalence estimates should be interpreted cautiously. Fourth, although 5+ NSSI days is one of the central criteria for the recently proposed NSSI disorder in the DSM-5, this was operationalized as five or more NSSI acts in the past year, and we did not assess full diagnostic criteria and had no information on the age-of-onset of potential NSSI disorder. Hence, we could not determine to what extent the presence of NSSI without meeting diagnostic criteria for NSSI disorder remains associated with later risk of mental disorders. Therefore, future prospective cohort studies should consider the risk factor status of NSSI disorder versus behavior in predicting secondary mental disorders during adolescence and (emerging) adulthood. Finally, as the present sample consists of first-year students, studies are needed that examine the relationship between NSSI and mental disorders during the college period. In light of the present findings, future investigations should differentiate meaningfully different developmental patterns (Hamza \& Willoughby, 2014), as the salience of diagnostic factors that predict NSSI onset (Kiekens et al., 2019) may be different from those predicting NSSI persistence among students with an onset of NSSI before entering college (Kiekens et al., 2017; Steinhoff et al., 2020). Addressing this knowledge gap may provide valuable information for the prevention of NSSI among college students.

These limitations notwithstanding, the present study presents the first cross-national data on NSSI among first-year college students. NSSI is a prevalent mental health concern among incoming students worldwide, with one in 12 reporting self-injury in the previous year. Further, findings confirm that diverse mental disorders are associated with NSSI and provide evidence suggesting that NSSI may be a behavioral marker or risk factor for subsequent mental disorders. 
Together, these findings underscore the need for an effective institutional response to self-injury among college students (Lewis et al., 2019). Appropriate and effective interventions that target adolescents with a history of NSSI may hold the potential to help offset future impairment and disease burden among college students. Before implementing such interventions, future studies that use prospective designs are needed to replicate the findings reported here and evaluate whether NSSI has any predictive value in determining the onset and persistence of mental disorders during the college years after controlling for disorder severity indicators.

\section{Disclosures/Conflicts of Interest}

Dr. Auerbach serves on the scientific advisory board for Ksana Health. Dr. Ebert reports to have received consultancy fees/served on the scientific advisory board for Sanofi, Novartis, Minddistrict, Lantern, Schoen Kliniken, and two German health insurance companies (BARMER, Techniker Krankenkasse). He is also a stakeholder in the Institute for health training online (GET.ON), which aims to implement scientific findings related to digital health interventions into routine care. In the past 3 years, Dr. Kessler was a consultant for Datastat, Inc., Holmusk, RallyPoint Networks, Inc., and Sage Pharmaceuticals. He has stock options in Mirah, PYM, and Roga Sciences. 


\section{WHO WMH-ICS Collaborators.}

Australia: Penelope Hasking (PI), Mark Boyes, David Preece, (School of Psychology, Curtin University); Belgium: Ronny Bruffaerts (PI), Erik Bootsma, Koen Demyttenaere, Glenn Kiekens (KU Leuven); France: Mathilde Husky (PI), Université de Bordeaux; Viviane Kovess-Masfety, Ecole des Hautes Etudes en Santé Publique; Germany: David D. Ebert (PI), Matthias Berking, Marvin Franke, Fanny Kählke (Friedrich-Alexander University Erlangen Nuremberg); Harald Baumeister, Ann-Marie Küchler (University of Ulm); Hong Kong: Arthur Mak (PI), Chinese University of Hong Kong; Siu Oi-ling, Lingnan University; Mexico: Corina Benjet (PI), Yesica Albor, Guilherme Borges, María Elena Medina-Mora, (Instituto Nacional de Psiquiatría Ramón de la Fuente); Alicia Edith Hermosillo de la Torre, Kalina Isela Martínez Martínez (Universidad Autónoma de Aguascalientes); Rebeca Guzmán Saldaña (Universidad Autónoma del Estado de Hidalgo); Ana María Martínez Jérez (Universidad Autónoma de Tamaulipas); Adrián Abrego Ramírez (Universidad Cuauhtémoc y Universidad Politécnica de Aguascalientes); Ma. Socorro Durán, Gustavo Pérez Tarango, María Alicia Zavala Berbena (Universidad De La Salle Bajío, campus Campestre); Rogaciano González González, Raúl A. Gutiérrez-García, Maria Abigail Paz Pérez (Universidad De La Salle Bajío, campus Salamanca); Anabell Covarrubias Díaz-Couder (Universidad La Salle Noroeste); Sinead Martínez Ruiz (Universidad La Salle Pachuca);

Netherlands: Pim Cuijpers (PI), Eirini Karyotaki (VU University Amsterdam); Northern Ireland: Siobhan O’Neill (PI), (School of Psychology, Ulster University); Tony Bjourson, Margaret McLafferty, Elaine Murray, (School of Biomedical Sciences, Ulster University); South Africa:

Dan J. Stein (PI), (Department of Psychiatry and Mental Health, SA MRC Unit on Risk \& Resilience in Mental Disorders, University of Cape Town); Christine Lochner, Janine Roos, Lian Taljaard, (SA MRC Unit on Risk \& Resilience in Mental Disorders, Department of Psychiatry, Stellenbosch University); Jason Bantjes, Wylene Saal, (Department of Psychology, Stellenbosch University); Spain: The UNIVERSAL study Group (Universidad y Salud Mental) includes: Jordi 
Alonso (PI), Gemma Vilagut, Philippe Mortier, (IMIM-Hospital del Mar Medical Research Institute/CIBERESP); Itxaso Alayo, Laura Ballester, Gabriela Barbaglia, Maria Jesús Blasco, Pere Castellví, Ana Isabel Cebrià, Carlos García-Forero, Andrea Miranda-Mendizábal, Oleguer ParèsBadell (Pompeu Fabra University); José Almenara, Carolina Lagares (Cadiz University), Enrique Echeburúa, Andrea Gabilondo, Álvaro Iruin (Basque Country University); María Teresa PérezVázquez, José Antonio Piqueras, Victoria Soto-Sanz, Jesús Rodríguez-Marín (Miguel Hernández University); and Miquel Roca, Margarida Gili, Margarida Vives (Illes Balears University); USA:

Randy P. Auerbach (PI) (Columbia University); Ronald C. Kessler (PI), (Harvard Medical School); Jennifer G. Green, (Boston University); Matthew K. Nock, (Harvard University); Stephanie Pinder-Amaker, (McLean Hospital and Harvard Medical School); Alan M. Zaslavsky (Harvard Medical School). 


\section{References}

American College Health Association (ACHA). (2018). American College Health AssociationNational College Health Assessment II: Undergraduate student reference group executive summary. Retrieved from https://www.acha.org/documents/ncha/NCHAII_Spring_2018_Undergraduate_Reference_Group_Executive_Summary.pdf

Alonso, J., Mortier, P., Auerbach, R. P., Bruffaerts, R., Vilagut, G., Cuijpers, P.,...Kessler, R. C. (2018). Severe role impairment associated with mental disorders: Results of the WHO World Mental Health Surveys International College Student project. Depression and Anxiety, 35(9), 802-814. doi: 10.1002/da.22778

American Psychiatric Association (APA). (2013). The Diagnostic and Statistical Manual of Mental Disorders, Fifth Edition. Arlington, VA: American Psychiatric Association.

Arnett, J. J. (2015). Emerging Adulthood: The winding road from the late teens through the twenties (2nd ed.). New York: Oxford University Press.

Arnett, J. J. (2016). College students as emerging adults: The developmental implications of the college context. Emerging Adulthood, 4(3), 219-222. doi:10.1177/2167696815587422

Arnett, J. J., Žukauskienè, R., \& Sugimura, K. (2014). The new life stage of emerging adulthood at ages 18-29 years: Implications for mental health. The Lancet Psychiatry, 1(7), 569-576. doi:10.1016/S2215-0366(14)00080-7

Auerbach, R. P., Alonso, J., Axinn, W. G., Cuijpers, P., Ebert, D. D., Green, J. G.,...Bruffaerts, R. (2016). Mental disorders among college students in the World Health Organization world mental health surveys. Psychological Medicine, 46(14), 2955-2970. doi:10.1017/S0033291716001665

Auerbach, R. P., Mortier, P., Bruffaerts, R., Alonso, J., Benjet, C., Cuijpers, P.,...Kessler, R. C. (2018). WHO world mental health surveys international college student project: 
Prevalence and distribution of mental disorders. Journal of Abnormal Psychology, 127(7), 623-638. doi:10.1037/abn0000362

Babor, T. F., Higgings-Biddle, J. C., Saunders, J. B., \& Monteiro, M. G. (2001). The alcohol use disorders identification test. Guidelines for use in Primary Care. Retrieved from http:// whqlibdoc.who.int/hq/2001/who_msd_msb_01.6a.pdf

Ballester, L., Alayo, I., Vilagut, G., Almenara, J., Cebria, A. I., Echeburua, E.,...Alonso, J. (2019). Accuracy of online survey assessment of mental disorders and suicidal thoughts and behaviors in Spanish university students. Results of the WHO World Mental HealthInternational College Student initiative. Public Library of Science One, 14(9), e0221529. doi:10.1371/journal.pone.0221529

Batejan, K. L., Jarvi, S. M., \& Swenson, L. P. (2015). Sexual orientation and non-suicidal selfinjury: A meta-analytic review. Archives of Suicide Research, 19(2), 131-150. doi:10.1080/13811118.2014.957450

Benjet, C., Gonzalez-Herrera, I., Castro-Silva, E., Mendez, E., Borges, G., Casanova, L., \& Medina-Mora, M. E. (2017). Non-suicidal self-injury in Mexican young adults: Prevalence, associations with suicidal behavior and psychiatric disorders, and DSM-5 proposed diagnostic criteria. Journal of Affective Disorders, 215, 1-8. doi:10.1016/j.jad.2017.03.025

Bentley, K. H., Cassiello-Robbins, C. F., Vittorio, L., Sauer-Zavala, S., \& Barlow, D. H. (2015). The association between nonsuicidal self-injury and the emotional disorders: A metaanalytic review. Clinical Psychology Review, 37, 72-88. doi:10.1016/j.cpr.2015.02.006

Bresin, K., \& Schoenleber, M. (2015). Gender differences in the prevalence of nonsuicidal selfinjury: A meta-analysis. Clinical Psychology Review, 38, 55-64. doi:10.1016/j.cpr.2015.02.009

Bruffaerts, R., Mortier, P., Auerbach, R. P., Alonso, J., Hermosillo De la Torre, A. E., Cuijpers, P.,...Kessler, R. C. (2019). Lifetime and 12-month treatment for mental disorders and 
suicidal thoughts and behaviors among first year college students. International Journal of Methods in Psychiatric Research, 28(2), e1764. doi:10.1002/mpr.1764

Bruffaerts, R., Mortier, P., Kiekens, G., Auerbach, R. P., Cuijpers, P., Demyttenaere, K.,...Kessler, R. C. (2018). Mental health problems in college freshmen: Prevalence and academic functioning. Journal of Affective Disorders, 225, 97-103. doi:10.1016/j.jad.2017.07.044

Buelens, T., Luyckx, K., Gandhi, A., Kiekens, G., \& Claes, L. (2019). Non-suicidal self-injury in adolescence: Longitudinal associations with psychological distress and rumination. Journal of Abnormal Child Psychology, 47(9), 1569-1581. doi:10.1007/s10802-019$00531-8$

Bureau of Labor Statistics (BLS). (2017). College enrollment and work activity of 2016 high school graduates. Retrieved from https://www.bls.gov/news.release/archives/hsgec_04272017.pdf

Burke, T. A., Fox, K., Kautz, M., Siegel, D. M., Kleiman, E., \& Alloy, L. B. (2021). Real-time monitoring of the associations between self-critical and self-punishment cognitions and nonsuicidal self-injury. Behaviour Research and Therapy, 137, 103775. doi:10.1016/j.brat.2020.103775

Burke, T. A., Hamilton, J. L., Abramson, L. Y., \& Alloy, L. B. (2015). Non-suicidal self-injury prospectively predicts interpersonal stressful life events and depressive symptoms among adolescent girls. Psychiatry Research, 228(3), 416-424.

doi:10.1016/j.psychres.2015.06.021

Burke, T. A., Piccirillo, M. L., Moore-Berg, S. L., Alloy, L. B., \& Heimberg, R. G. (2019). The stigmatization of nonsuicidal self-injury. Journal of Clinical Psychology, 75(3), 481-498. doi:10.1002/jclp.22713

Cuijpers, P., Auerbach, R. P., Benjet, C., Bruffaerts, R., Ebert, D., Karyotaki, E., \& Kessler, R. C. (2019). Introduction to the special issue: The WHO World Mental Health International 
College Student (WMH-ICS) initiative. International Journal of Methods in Psychiatric Research 28(2), e1762. doi:10.1002/mpr.1762

Cvetkovski, S., Reavley, N. J., \& Jorm, A. F. (2012). The prevalence and correlates of psychological distress in Australian tertiary students compared to their community peers. Australian \& New Zealand Journal of Psychiatry, 46(5), 457-467. doi:10.1177/0004867411435290

Daukantaitė, D., Lundh, L.-G., Wångby-Lundh, M., Claréus, B., Bjärehed, J., Zhou, Y., \& Liljedahl, S. I. (2020). What happens to young adults who have engaged in self-injurious behavior as adolescents? A 10-year follow-up. European Child \& Adolescent Psychiatry, 30(3), 475-492. doi:10.1007/s00787-020-01533-4

Duffy, M. E., Twenge, J. M., \& Joiner, T. E. (2019). Trends in mood and anxiety symptoms and suicide-related outcomes among U.S. undergraduates, 2007-2018: Evidence from two national surveys. Journal of Adolescent Health, 65, 590-8.

doi:10.1016/j.jadohealth.2019.04.033

Ebert, D. D., Mortier, P., Kaehlke, F., Bruffaerts, R., Baumeister, H., Auerbach, R. P.,...Kessler, R. C. (2019). Barriers of mental health treatment utilization among first-year college students: First cross-national results from the WHO World Mental Health International College Student initiative. International Journal of Methods in Psychiatric Research, 28(2), e1782. doi:10.1002/mpr.1782

Efron, B. (1988). Logistic regression, survival analysis, and the Kaplan-Meier curve. Journal of the American Statistical Association, 83(402), 414-425. doi:10.1080/01621459.1988.10478612

Fox, K. R., Franklin, J. C., Ribeiro, J. D., Kleiman, E. M., Bentley, K. H., \& Nock, M. K. (2015). Meta-analysis of risk factors for nonsuicidal self-injury. Clinical Psychology Review, 42, 156-167. doi:10.1016/j.cpr.2015.09.002 
Fox, K. R., Harris, J. A., Wang, S. B., Millner, A. J., Deming, C. A., \& Nock, M. K. (2020). Selfinjurious thoughts and behaviors interview-revised: Development, reliability, and validity. Psychological Assessment, 32(7), 677-689. doi:10.1037/pas0000819

Gandhi, A., Luyckx, K., Baetens, I., Kiekens, G., Sleuwaegen, E., Berens, A.,...Claes, L. (2018). Age of onset of non-suicidal self-injury in Dutch-speaking adolescents and emerging adults: An event history analysis of pooled data. Comprehensive Psychiatry, 80, 170-178. doi:10.1016/j.comppsych.2017.10.007

Gillies, D., Christou, M. A., Dixon, A. C., Featherston, O. J., Rapti, I., Garcia-Anguita, A.,...Christou, P. A. (2018). Prevalence and characteristics of self-harm in adolescents: Meta-analyses of community-based studies 1990-2015. Journal of the American Academy of Child \& Adolescent Psychiatry, 57(10), 733-741. doi:10.1016/j.jaac.2018.06.018

Glenn, C. R., Jaroszewski, A. C., Milner, A., Kearns, J. C., \& Nock, M. K. (2015). Nonsuicidal self-injury: Old problem, new disorder, limited data. In E. Bromet (Ed.), Long-term outcomes in psychopathology research: Rethinking the scientific agenda. (pp. 253-276). New York: Oxford University Press.

Glenn, C. R., \& Klonsky, E. D. (2011). Prospective prediction of nonsuicidal self-injury: A 1-year longitudinal study in young adults. Behavior Therapy, 42(4), 751-762. doi:10.1016/j.beth.2011.04.005

Goldstein, H. (2011). Multilevel statistical models (4th ed.). New York: John Wiley \& Sons. Green, J. G., McLaughlin, K. A., Berglund, P. A., Gruber, M. J., Sampson, N. A., Zaslavsky, A. M., \& Kessler, R. C. (2010). Childhood adversities and adult psychiatric disorders in the national comorbidity survey replication 1: Associations with first onset of DSM-IV disorders. Archives of General Psychiatry, 67(2), 113-123.

doi:10.1001/archgenpsychiatry.2009.186 
Hamza, C., Goldstein, A. L., Heath, N. L., \& Ewing, L. (2021). Stressful experiences in university predict nonsuicidal self-injury through emotional reactivity. Frontiers in Psychology, 12. doi:10.3389/fpsyg.2021.610670

Hamza, C. A., \& Willoughby, T. (2014). A longitudinal person-centered examination of nonsuicidal self-injury among university students. Journal of Youth and Adolescence, 43(4), 671-685. doi:10.1007/s10964-013-9991-8

Hamza, C. A., \& Willoughby, T. (2016). Nonsuicidal self-injury and suicidal risk among emerging adults. Journal of Youth and Adolescence, 59(4), 411-415. doi:10.1016/j.jadohealth.2016.05.019

Hasking, P., Whitlock, J., Voon, D., \& Rose, A. (2017). A cognitive-emotional model of NSSI: Using emotion regulation and cognitive processes to explain why people self-injure. Cognition and Emotion, 31(8), 1543-1556. doi:10.1080/02699931.2016.1241219

Hepp, J., Carpenter, R. W., Störkel, L. M., Schmitz, S. E., Schmahl, C., \& Niedtfeld, I. (2020). A systematic review of daily life studies on non-suicidal self-injury based on the fourfunction model. Clinical Psychology Review, 82, 101888. doi:10.1016/j.cpr.2020.101888

Hooley, J. M., \& Franklin, J. C. (2017). Why do people hurt themselves? A new conceptual model of nonsuicidal self-injury. Clinical Psychological Science, 6(3), 428-451. doi:10.1177/2167702617745641

Hunt, J., \& Eisenberg, D. (2010). Mental health problems and help-seeking behavior among college students. Journal of Adolescent Health, 46(1), 3-10. doi:10.1016/j.jadohealth.2009.08.008

International Society for the Study of Self-injury (ISSS). (2018). What is nonsuicidal self-injury? Retrieved from https://itriples.org/about-self-injury/what-is-self-injury

Karyotaki, E., Cuijpers, P., Albor, Y., Alonso, J., Auerbach, R. P., Bantjes, J.,...Kessler, R. C. (2020). Sources of stress and their associations with mental disorders among college students: Results of the World Health Organization World Mental Health Surveys 
International College Student initiative. Frontiers in Psychology, 11, 1-11. doi:10.3389/fpsyg.2020.01759

Kessler, R. C., Calabrese, J. R., Farley, P. A., Gruber, M. J., Jewell, M. A., Katon, W.,...Wittchen, H. U. (2013). Composite international diagnostic interview screening scales for DSM-IV anxiety and mood disorders. Psychological Medicine, 43(8), 1625-1637. doi:10.1017/S0033291712002334

Kessler, R. C., Santiago, P. N., Colpe, L. J., Dempsey, C. L., First, M. B., Heeringa, S. G.,...Ursano, R. J. (2013). Clinical reappraisal of the Composite International Diagnostic Interview Screening Scales (CIDI-SC) in the Army Study to Assess Risk and Resilience in Servicemembers (Army STARRS). International Journal of Methods Psychiatric Research, 22(4), 303-321. doi:10.1002/mpr.1398

Kessler, R. C., \& Ustun, T. B. (2004). The World Mental Health (WMH) Survey Initiative Version of the World Health Organization (WHO) Composite International Diagnostic Interview (CIDI). International Journal of Methods Psychiatric Research, 13(2), 93-121. doi:10.1002/mpr.168

Kiekens, G., Claes, L., Demyttenaere, K., Auerbach, R. P., Green, J. G., Kessler, R. C.,...Bruffaerts, R. (2016). Lifetime and 12-month nonsuicidal self-injury and academic performance in college freshmen. Suicide and Life-Threatening Behavior, 46(5), 563-576. doi:10.1111/sltb.12237

Kiekens, G., Hasking, P., Bruffaerts, R., Claes, L., Baetens, I., Boyes, M.,...Whitlock, J. (2017). What predicts ongoing nonsuicidal self-injury?: A comparison between persistent and ceased self-injury in emerging adults. Journal of Nervous and Mental Disease, 205(10), 762-770. doi:10.1097/NMD.0000000000000726

Kiekens, G., Hasking, P., Claes, L., Boyes, M., Mortier, P., Auerbach, R. P.,...Bruffaerts, R. (2019). Predicting the incidence of non-suicidal self-injury in college students. European Psychiatry, 59, 44-51. doi:10.1016/j.eurpsy.2019.04.002 
Kiekens, G., Hasking, P., Claes, L., Mortier, P., Auerbach, R. P., Boyes, M.,...Bruffaerts, R. (2018). The DSM-5 nonsuicidal self-injury disorder among incoming college students: Prevalence and associations with 12-month mental disorders and suicidal thoughts and behaviors. Depression \& Anxiety, 35(7), 629-637. doi:10.1002/da.22754

Kiekens, G., Hasking, P., Nock, M. K., Boyes, M., Kirtley, O., Bruffaerts, R.,...Claes, L. (2020). Fluctuations in affective states and self-efficacy to resist non-suicidal self-injury as realtime predictors of non-suicidal self-injurious thoughts and behaviors. Frontiers in Psychiatry, 11, 214. doi:10.3389/fpsyt.2020.00214

Kiekens, G., Robinson, K., Tatnell, R., \& Kirtley, O. J. (2021). Opening the black box of daily life in non-suicidal self-injury research: With great opportunity comes great responsibility. PsyArXiv. https://doi.org/10.31234/osf.io/yp86x

Latimer, S., Meade, T., \& Tennant, A. (2013). Measuring engagement in deliberate self-harm behaviours: Psychometric evaluation of six scales. BMC Psychiatry, 13(1), 4. doi:10.1186/1471-244X-13-4

Lewis, S. P., Heath, N. L., Hasking, P. A., Whitlock, J. L., Wilson, M. S., \& Plener, P. L. (2019). Addressing self-injury on college campuses: Institutional recommendations. Journal of College Counseling, 22(1), 70-82. doi:10.1002/jocc.12115

Magolda, M. B., \& Taylor, K. B. (2016). Developing self-authorship in college to navigate emerging adulthood. In J. J. Arnett (Ed.), The Oxford handbook of emerging adulthood (pp. 299-315). New York, NY: Oxford University Press.

Mortier, P., Auerbach, R. P., Alonso, J., Bantjes, J., Benjet, C., Cuijpers, P.,...Kessler, R. C. (2018a). Suicidal thoughts and behaviors among first-year college students: Results from the WMH-ICS Project. Journal of the American Academy of Child \& Adolescent Psychiatry, 57(4), 263-273.e1. doi:10.1016/j.jaac.2018.01.018

Mortier, P., Cuijpers, P., Kiekens, G., Auerbach, R. P., Demyttenaere, K., Green, J. G.,...Bruffaerts, R. (2018b). The prevalence of suicidal thoughts and behaviours among 
college students: A meta-analysis. Psychological Medicine, 48(4), 554-565. doi:10.1017/S0033291717002215

Mortier, P., Demyttenaere, K., Auerbach, R. P., Cuijpers, P., Green, J. G., Kiekens, G.,...Bruffaerts, R. (2017). First onset of suicidal thoughts and behaviours in college. Journal of Affective Disorders, 207, 291-299. doi:10.1016/j.jad.2016.09.033

Nock, M. K., Holmberg, E. B., Photos, V. I., \& Michel, B. D. (2007). Self-injurious thoughts and behaviors interview: Development, reliability, and validity in an adolescent sample. Psychological Assessment, 19(3), 309-317. doi:10.1037/1040-3590.19.3.309

Reinert, D. F., \& Allen, J. P. (2002). The Alcohol Use Disorders Identification Test (AUDIT): A review of recent research. Alcoholism Clinical and Experimental Research, 26(2), 272279. doi:10.1111/j.1530-0277.2002.tb02534.x

Robinson, K., Garisch, J. A., Kingi, T., Brocklesby, M., O’Connell, A., Langlands, R. L.,...Wilson, M. S. (2018). Reciprocal risk: The longitudinal relationship between emotion regulation and non-suicidal self-injury in adolescents. Journal of Abnormal Child Psychology, 47(2), 325-332. doi:10.1007/s10802-018-0450-6

Roser, M., \& Ortiz-Ospina, E. (2013). Tertiary education. Retrieved from https://ourworldindata.org/tertiary-education

Rubin, D. B. (1987). Multiple imputation for nonresponse in surveys. New York, NY: John Wiley $\&$ Sons.

Saunders, J. B., Aasland, O. G., Babor, T. F., de la Fuente, J. R., \& Grant, M. (1993). Development of the Alcohol Use Disorders Identification Test (AUDIT): WHO collaborative project on early detection of persons with harmful alcohol consumption-II. Addiction, 88(6), 791-804. doi:10.1111/j.1360-0443.1993.tb02093.x

Shahar, G., Bareket, L., Rudd, M., \& Joiner, T. (2006). In severely suicidal young adults, hopelessness, depressive symptoms, and suicidal ideation constitute a single syndrome. Psychological Medicine, 36(7), 913-922. doi:10.1017/S0033291706007586 
Shahar, G., \& Henrich, C. C. (2019). Role of adolescent exposure to rockets in the links between personality vulnerability and psychopathology. Development and Psychopathology, 31(4), 1367-1380. doi:10.1017/S0954579418000792

Shulman, S., \& Connolly, J. (2013). The challenge of romantic relationships in emerging adulthood: Reconceptualization of the field. Emerging Adulthood, 1(1), 27-39. doi:10.1177/2167696812467330

Selby, E. A., Kranzler, A., Fehling, K. B., \& Panza, E. (2015). Nonsuicidal self-injury disorder: The path to diagnostic validity and final obstacles. Clinical Psychology Review, 38, 79-91. doi:10.1016/j.cpr.2015.03.003

Serras, A., Saules, K. K., Cranford, J. A., \& Eisenberg, D. (2010). Self-injury, substance use, and associated risk factors in a multi-campus probability sample of college students. Psychology of Addictive Behaviors, 24(1), 119-28. doi:10.1037/a0017210

Staniland, L., Hasking, P., Boyes, M., \& Lewis, S. (2020). Stigma and nonsuicidal self-injury: Application of a conceptual framework. Stigma and Health. doi:10.1037/sah0000257

Steinhoff, A., Ribeaud, D., Kupferschmid, S., Raible-Destan, N., Quednow, B. B., Hepp, U.,...Shanahan, L. (2020). Self-injury from early adolescence to early adulthood: Agerelated course, recurrence, and services use in males and females from the community. European Child \& Adolescent Psychiatry, 1-15. doi:10.1007/s00787-020-01573-w

Swannell, S. V., Martin, G. E., Page, A., Hasking, P., \& St John, N. J. (2014). Prevalence of nonsuicidal self-injury in nonclinical samples: Systematic review, meta-analysis and metaregression. Suicide and Life-Threatening Behavior, 44, 273-303. doi:10.1111/s1tb.12070

Taliaferro, L. A., \& Muehlenkamp, J. J. (2015). Risk factors associated with self-injurious behavior among a national sample of undergraduate college students. Journal of American College Health, 63(1), 40-48. doi:10.1080/07448481.2014.953166 
van Buuren, S. (2007). Multiple imputation of discrete and continuous data by fully conditional specification. Statistical Methods in Medical Research, 16(3), 219-242. doi:10.1177/0962280206074463

Waals, L., Baetens, I., Rober, P., Lewis, S., Van Parys, H., Goethals, E. R., \& Whitlock, J. (2018). The NSSI family distress cascade theory. Child and Adolescent Psychiatry and Mental Health, 12(1), 1-6. doi:10.1186/s13034-018-0259-7

Wester, K., Trepal, H., \& King, K. (2018). Nonsuicidal self-injury: Increased prevalence in engagement. Suicide and Life-Threatening Behavior, 48(6), 690-698. doi:10.1111/sltb.12389

Whitlock, J., Muehlenkamp, J. J., Purington, A., Eckenrode, J., Barreira, P., Baral Abrams, G.,...Knox, K. (2011). Nonsuicidal self-injury in a college population: General trends and sex differences. Journal of American College Health, 59(8), 691-698. doi:10.1080/07448481.2010.529626

Wilcox, H. C., Arria, A. M., Caldeira, K. M., Vincent, K. B., Pinchevsky, G. M., \& O'Grady, K. E. (2012). Longitudinal predictors of past-year non-suicidal self-injury and motives among college students. Psychological Medicine, 42(4), 717-726. doi:10.1017/S0033291711001814

Wilkinson, P. O., Qiu, T., Neufeld, S., Jones, P. B., \& Goodyer, I. M. (2018). Sporadic and recurrent non-suicidal self-injury before age 14 and incident onset of psychiatric disorders by 17 years: Prospective cohort study. Britisch Journal of Psychiatry, 212(4), 222-226. doi:10.1192/bjp.2017.45 


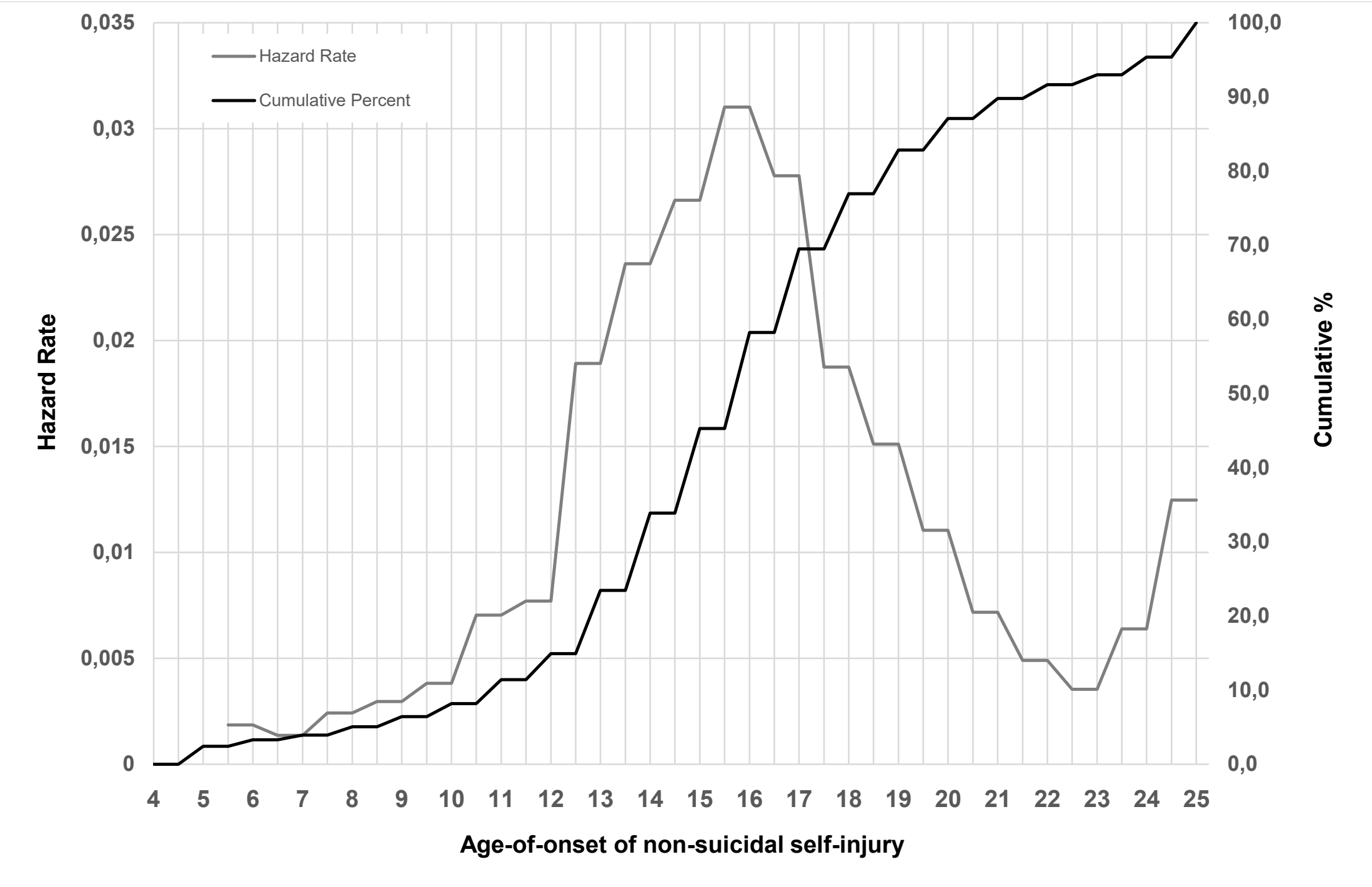

Figure 1. Hazard rate and cumulative age-of-onset distribution for non-suicidal self-injury in WMH-ICS. Note: Projected age of onset are based on first-year students, limiting the representativeness of the estimated distributions above age 18 to 19 years (i.e., the typical age of entering college). 
Table 1.

Lifetime prevalence of DSM-IV mental disorders and temporal priorities with non-suicidal self-injury in the WMH-ICS $(\mathrm{n}=20,842)$.

Lifetime prevalence

Respondents with both lifetime mental disorder of interest and lifetime non-suicidal self-injury

DSM-IV mental disorders

\begin{tabular}{ccc}
\hline Respondents & Respondents & Odds Ratio \\
with no & reporting & between lifetime \\
history of & lifetime & NSSI and lifetime
\end{tabular}

Weighted NSSI onset

number of prior to

NSSI onset
and disorder

NSSI onset

Goodness-of-Fit

history of lifetime NSSI and lifetime

respondents disorder onset

onset in the

after disorder

Test for Equal

$\%(\mathrm{SE})$
OR $(95 \% \mathrm{CI})$

$$
\% \text { (SE) }
$$

same year

onset \%(SE)

Proportion F-

$$
\%(\mathrm{SE})
$$

Major depressive disorder $11.6(0.3)$

$35.2(0.8)$

$4.2(3.8-4.5)^{*}$

1303

$32.7(1.3)$

$23.2(1.2)$

$44.1(1.4)$

value $[p-v a l u e]^{a}$

Generalized anxiety disorder $10.8(0.3)$

Panic disorder $2.5(0.2)$

$33.2(0.8)$

$4.1(3.7-4.5)^{*}$

$42.7(1.5)$

$18.4(1.2)$

$48.3(2.8)$

$17.5(2.1)$

$38.9(1.4)$

$5.0(4.3-5.9)^{*}$

$52.4(2.7)$

$16.9(2.1)$

$9.3(0.5)$

$4.4(3.8-5.2)^{*}$

345

Alcohol use disorder $6.3(0.2)$

$10.3(0.6)$

$1.7(1.5-2.0)^{*}$

$68.9(2.7)$

$11.3(1.7)$

$34.2(2.7)$

$22.54[0.00]^{*}$

Drug use disorder $2.6(0.2)$

$7.3(0.5)$

$2.9(2.5-3.5)^{*}$

$69.8(3.1)$

$15.6(2.4)$

$30.7(2.5)$

$19.8(2.2)$

$2.24[0.13]$

Any disorder $25.0(0.4)$

$59.6(0.8) \quad 4.4(4.1-4.8)^{*}$

270

-

$-$

$14.6(2.4)$

$20.53[0.00]^{*}$

$95.53[0.00]^{*}$

$89.10[0.00]^{*}$

Note: ${ }^{\text {a }}$ F-test to evaluate significance of pooled Chi-square goodness-of-fit test across 20 imputed datasets on a reduced subset of respondents comparing percent with onset of non-suicidal selfinjury prior to disorder onset versus percent with onset of non-suicidal self-injury after mental disorder onset. NSSI = Non-Suicidal Self-Injury. ${ }^{*}$ Significant at the .05 level, two-sided test. 
Table 2.

Bivariate associations between temporally prior DSM-IV mental disorders and subsequent non-suicidal self-injury in the WMH-ICS.

\begin{tabular}{|c|c|c|c|}
\hline & $\begin{array}{c}\text { Onset: } \\
\text { Lifetime NSSI }{ }^{\mathrm{a}} \text { among } \\
\text { the entire sample }\end{array}$ & $\begin{array}{c}\text { Recency: } \\
\text { 12-month NSSI }{ }^{\mathrm{b}} \text { among } \\
\text { sample reporting } \\
\text { lifetime NSSI }\end{array}$ & $\begin{array}{c}\text { Severity: } \\
\text { 5+ frequency criterion } \\
\text { among sample }^{c} \\
\text { reporting } 12-\text { month } \\
\text { NSSI } \\
\end{array}$ \\
\hline & Bivariate aOR $(95 \% \mathrm{CI})$ & Bivariate aOR $(95 \% \mathrm{CI})$ & Bivariate aOR $(95 \% \mathrm{CI})$ \\
\hline \multicolumn{4}{|l|}{ Temporally prior mental disorder } \\
\hline Major depressive disorder & $3.3(3.0-3.7)^{*}$ & $1.3(1.0-1.6)^{*}$ & $1.5(1.1-2.1)^{*}$ \\
\hline Generalized anxiety disorder & $2.7(2.5-3.1)^{*}$ & $1.4(1.1-1.7)^{*}$ & $1.7(1.2-2.3)^{*}$ \\
\hline Panic disorder & $2.8(2.2-3.5)^{*}$ & $2.5(1.6-3.9)^{*}$ & $1.8(1.0-3.1)^{*}$ \\
\hline Bipolar disorder & $3.0(2.4-3.7)^{*}$ & $1.6(1.1-2.5)^{*}$ & $1.8(1.0-3.4)$ \\
\hline Alcohol use disorder & $1.6(1.2-2.0)^{*}$ & $1.8(1.1-3.2)^{*}$ & $2.1(1.0-4.5)^{*}$ \\
\hline Drug use disorder & $1.7(1.1-2.4)^{*}$ & $1.4(0.6-3.3)$ & $1.0(0.3-3.1)$ \\
\hline Any mental disorder & $3.1(2.8-3.4)^{*}$ & $1.5(1.2-1.8)^{*}$ & $1.7(1.3-2.3)^{*}$ \\
\hline \multicolumn{4}{|l|}{ Number of temporally prior mental disorders } \\
\hline $\begin{array}{ll} & \\
\text { None }\end{array}$ & (ref) & (ref) & (ref) \\
\hline Exactly one mental disorder & $2.7(2.5-3.0)^{*}$ & $1.3(1.1-1.7)^{*}$ & $1.5(1.1-2.1)^{*}$ \\
\hline Exactly two mental disorders & $4.2(3.7-4.9)^{*}$ & $1.7(1.2-2.3)^{*}$ & $2.1(1.4-3.3)^{*}$ \\
\hline Three or more mental disorders & $4.2(3.0-5.7)^{*}$ & $3.0(1.5-6.4)^{*}$ & $2.3(1.0-5.6)$ \\
\hline$F(n d f, d d f)[p \text { value }]^{d}$ & $220.96(3,1806)[0.00]^{*}$ & $8.69(3,14742)[0.00]^{*}$ & $6.10(3,1872)[0.00]^{*}$ \\
\hline
\end{tabular}

in lifetime, ${ }^{\mathrm{b}} \mathrm{NSSI}$ at least once in past 12 -months, ${ }^{\mathrm{c}} \mathrm{NSSI}$ at least five times in past 12 -months, ${ }^{\mathrm{d}}$ F-test to evaluate joint significance of number of mental disorders across 20 imputed datasets. Each cell displays the result of a separate bivariate model within a person-period survival (onset models) or personlevel time-order (recency and severity models) framework, including the disorder specified in the row as predictor controlling for the following covariates: country membership, gender, age (onset models), education, marital status parents, religion, sexual orientation, person-year (onset models), high-school ranking (recency and severity models), age-of-onset NSSI (recency and severity models), and time since onset NSSI (recency and severity models). NSSI = Non-Suicidal Self-Injury, $\mathrm{ndf}=$ numerator degrees of freedom, $\mathrm{ddf}=$ denominator degrees of freedom.

*Significant at the .05 level, two-sided test. 
Table 3.

Multivariate associations between temporally prior DSM-IV mental disorders and subsequent non-suicidal self-injury in the WMH-ICS.

\begin{tabular}{|c|c|c|c|c|c|c|}
\hline & \multicolumn{2}{|c|}{$\begin{array}{c}\text { Onset: } \\
\text { Lifetime NSSI }{ }^{\mathrm{a}} \text { among the } \\
\text { entire sample }\end{array}$} & \multicolumn{2}{|c|}{$\begin{array}{c}\text { Recency: } \\
\text { 12-month NSSI }{ }^{\mathrm{b}} \text { among sample } \\
\text { reporting lifetime NSSI }\end{array}$} & \multicolumn{2}{|c|}{$\begin{array}{c}\text { Severity: } \\
\text { 5+ frequency criterion }{ }^{\mathrm{c}} \text { among } \\
\text { sample reporting } 12 \text {-month } \\
\text { NSSI } \\
\end{array}$} \\
\hline & $\begin{array}{l}\text { Multivariate } \\
\text { additive } \\
\text { aOR }(95 \% \mathrm{CI})\end{array}$ & $\begin{array}{c}\text { Multivariate } \\
\text { interactive } \\
\mathrm{aOR}(95 \% \mathrm{CI})\end{array}$ & $\begin{array}{l}\text { Multivariate } \\
\text { additive } \\
\text { aOR }(95 \% \mathrm{CI})\end{array}$ & $\begin{array}{c}\text { Multivariate } \\
\text { interactive } \\
\text { aOR }(95 \% \mathrm{CI})\end{array}$ & $\begin{array}{l}\text { Multivariate } \\
\text { additive } \\
\text { aOR }(95 \% \mathrm{CI})\end{array}$ & $\begin{array}{l}\text { Multivariate } \\
\text { interactive } \\
\mathrm{aOR}(95 \% \mathrm{CI})\end{array}$ \\
\hline \multicolumn{7}{|c|}{ Temporally prior mental disorder } \\
\hline Major depressive disorder & $2.8(2.5-3.2)^{*}$ & $3.3(2.9-3.8)^{*}$ & $1.2(1.0-1.5)$ & $1.3(1.0-1.6)$ & $1.4(1.0-2.0)^{*}$ & $1.5(1.0-2.2)^{*}$ \\
\hline Generalized anxiety disorder & $1.6(1.4-1.9)^{*}$ & $2.2(1.9-2.6)^{*}$ & $1.2(0.9-1.5)$ & $1.2(0.9-1.7)$ & $1.4(1.0-2.0)$ & $1.6(1.0-2.5)$ \\
\hline Panic disorder & $1.7(1.3-2.1)^{*}$ & $2.6(2.0-3.4)^{*}$ & $2.3(1.4-3.6)^{*}$ & $2.4(1.4-4.0)^{*}$ & $1.4(0.8-2.6)$ & $1.7(0.9-3.4)$ \\
\hline Bipolar disorder & $2.8(2.2-3.5)^{*}$ & $3.4(2.7-4.2)^{*}$ & $1.4(0.9-2.2)$ & $1.5(0.9-2.4)$ & $1.6(0.9-3.0)$ & $1.8(1.0-3.5)$ \\
\hline Alcohol use disorder & $1.2(0.9-1.6)$ & $1.6(1.2-2.1)^{*}$ & $1.7(1.0-2.9)$ & $1.7(1.0-3.1)$ & $1.9(0.9-4.0)$ & $2.2(1.0-4.8)$ \\
\hline Drug use disorder & $1.2(0.8-1.8)$ & $1.7(1.1-2.5)^{*}$ & $1.2(0.5-2.9)$ & $1.2(0.5-3.1)$ & $0.7(0.2-2.4)$ & $0.9(0.3-2.9)$ \\
\hline $\mathrm{F}(\mathrm{ndf}, \mathrm{ddf})[\mathrm{p} \text { value }]^{\mathrm{d}}$ & $\begin{array}{c}114.06(6,737) \\
{[0.00]^{*}}\end{array}$ & $\begin{array}{c}70.90(6,1817) \\
{[0.00]^{*}}\end{array}$ & $\begin{array}{c}5.09(6,1671) \\
{[0.00]^{*}}\end{array}$ & $\begin{array}{l}2.30(6,531) \\
{[0.03]^{*}}\end{array}$ & $\begin{array}{c}3.60(6,4067) \\
{[0.00]^{*}}\end{array}$ & $\begin{array}{c}1.71(6,1855) \\
{[0.11]}\end{array}$ \\
\hline$F($ ndf,ddf $)[p \text { value }]^{e}$ & - & $\begin{array}{c}6.89(5,5940) \\
{[0.00]^{*}}\end{array}$ & - & $\begin{array}{l}1.25(5,448) \\
\quad[0.28]\end{array}$ & - & $\begin{array}{c}0.48(5,2028) \\
{[0.79]}\end{array}$ \\
\hline \multicolumn{7}{|c|}{$\begin{array}{l}\text { Number of temporally prior mental } \\
\text { disorders }\end{array}$} \\
\hline None & - & (ref) & - & (ref) & - & (ref) \\
\hline Exactly one mental disorder & - & (ref) & - & (ref) & - & (ref) \\
\hline Exactly two mental disorders & - & $0.6(0.5-0.8)^{*}$ & - & $0.9(0.6-1.5)$ & - & $0.9(0.4-1.7)$ \\
\hline Three or more mental disorders & - & $0.2(0.1-0.4)^{*}$ & - & $0.9(0.3-2.5)$ & - & $0.5(0.1-2.0)$ \\
\hline $\mathrm{F}(\mathrm{ndf}, \mathrm{ddf})[\mathrm{p} \text { value }]^{\mathrm{f}}$ & - & $\begin{array}{c}20.29(2,1182) \\
{[0.00]^{*}} \\
\end{array}$ & - & $\begin{array}{c}0.11(2,496) \\
{[0.90]}\end{array}$ & - & $\begin{array}{c}0.42(2,410) \\
{[0.66]}\end{array}$ \\
\hline
\end{tabular}

time, ${ }^{\mathrm{b}}$ NSSI at least once in past 12 -months, ${ }^{\mathrm{c}}$ NSSI at least five times in past 12 -months, ${ }^{\mathrm{d}}$ F-test to evaluate joint significance of six types of mental disorders across 20 imputed datasets, ${ }^{\mathrm{e}}$ F-test to evaluate significant between-disorder differences in estimates across 20 imputed datasets. ${ }^{\mathrm{f}} \mathrm{F}$-test to evaluate the significance of number of mental disorders across 20 imputed datasets. Each column of each model displays the result of a separate multivariate model within a person-period survival (onset models) or person-level time-order (recency and severity models) framework, with type of mental disorders (additive models) and type and number of mental disorders (interactive models) that occurred prior to NSSI as predictors, controlling for the following covariates: country membership, gender, age (onset models), education, marital status parents, religion, sexual orientation, person-year (onset models), high-school ranking (recency and severity models), age-of-onset NSSI (recency and severity models), and time since 
onset NSSI (recency and severity models). NSSI $=$ Non-Suicidal Self-Injury, $\mathrm{ndf}=$ numerator degrees of freedom, $\mathrm{ddf}=$ denominator degrees of freedom. $*$ Significant at the 05 level, two-sided test. 
Table 4.

Associations between temporally prior non-suicidal self-injury and onset and recency of DSM- IV mental disorders in the WMH-ICS.

\begin{tabular}{|c|c|c|c|c|}
\hline \multirow[b]{2}{*}{ DSM-IV Mental Disorders } & \multicolumn{2}{|c|}{ Disorder Onset } & \multicolumn{2}{|c|}{ Disorder Recency } \\
\hline & $\begin{array}{c}\text { Bivariate } \\
\mathrm{aOR}(95 \% \mathrm{CI})\end{array}$ & $\begin{array}{c}\text { Multivariate } \\
\text { aOR }(95 \% \mathrm{CI})\end{array}$ & $\begin{array}{c}\text { Bivariate aOR } \\
(95 \% \mathrm{CI})\end{array}$ & $\begin{array}{c}\text { Multivariate } \\
\text { aOR }(95 \% \mathrm{CI})\end{array}$ \\
\hline Major depressive disorder & $1.5(1.3-1.7)^{*}$ & $1.3(1.1-1.5)^{*}$ & $1.1(0.8-1.5)$ & $1.1(0.7-1.5)$ \\
\hline Generalized anxiety disorder & $2.1(1.9-2.3)^{*}$ & $1.4(1.3-1.6)^{*}$ & $1.7(1.1-2.4)^{*}$ & $1.6(1.1-2.3)^{*}$ \\
\hline Panic disorder & $2.6(2.1-3.2)^{*}$ & $1.7(1.4-2.1)^{*}$ & $1.0(0.4-2.7)$ & $1.1(0.4-2.8)$ \\
\hline Bipolar disorder & $3.1(2.5-3.8)^{*}$ & $2.0(1.6-2.5)^{*}$ & $5.0(1.5-16.4)^{*}$ & $4.6(1.4-15.4)^{*}$ \\
\hline Alcohol use disorder & $2.1(1.7-2.5)^{*}$ & $1.8(1.5-2.3)^{*}$ & $1.3(0.7-2.5)$ & $1.2(0.6-2.5)$ \\
\hline Drug use disorder & $2.5(2.1-3.1)^{*}$ & $1.8(1.5-2.3)^{*}$ & $1.1(0.7-1.9)$ & $1.0(0.6-1.8)$ \\
\hline
\end{tabular}




\section{SUPPLEMENTARY TABLES}

\section{Supplementary Table 1.}

WMH-ICS sample characteristics.

\begin{tabular}{|c|c|c|c|c|c|c|c|}
\hline Country & $\begin{array}{c}\text { Number of } \\
\text { participating } \\
\text { universities }\end{array}$ & $\begin{array}{c}\text { Total size of } \\
\text { the } \\
\text { universities }\end{array}$ & $\begin{array}{c}\text { Number of } \\
\text { first-year } \\
\text { students } \\
\text { eligible }\end{array}$ & $\begin{array}{c}\text { Number of } \\
\text { first-year } \\
\text { students } \\
\text { participated }\end{array}$ & $\begin{array}{c}\text { Response } \\
\text { Rate }\end{array}$ & $\begin{array}{l}\text { Survey } \\
\text { Field } \\
\text { Dates }\end{array}$ & Sampling and procedures \\
\hline Australia & 1 public & $\sim 45,000$ & 13,752 & 1,202 & $8.7 \%$ & 2016-17 & $\begin{array}{l}\text { All first-year students were invited to participate through e-mail. } \\
\text { Five reminder emails were sent with personalized links to the } \\
\text { survey. Conditional incentives were applied (movie passes). }\end{array}$ \\
\hline Belgium & 1 public & $\sim 45,000$ & 13,103 & 5,844 & $44.6 \%$ & $2014-17$ & $\begin{array}{l}\text { All first-year students between 2014-2016 were invited for a } \\
\text { psycho-medical check-up in the student mental health center. } \\
\text { Surveys were completed in the waiting room. Students who did not } \\
\text { show up for the psycho-medical check-up received up to eight } \\
\text { reminder emails. Conditional incentives were applied (store credit } \\
\text { coupons). In 2016-2017, all first-year students were invited to } \\
\text { participate through e-mail (up to eight emails). }\end{array}$ \\
\hline Germany & 2 public & $\sim 40,000$ & 11,210 & 1,757 & $15.7 \%$ & 2016-18 & $\begin{array}{l}\text { All first-year students were invited to participate through e-mail. Six } \\
\text { reminder emails were sent with personalized links to the survey. } \\
\text { Conditional incentives were applied (store credit coupons). }\end{array}$ \\
\hline Hongkong & 1 public & $\sim 3,000$ & 519 & 208 & $40.1 \%$ & 2017 & $\begin{array}{l}\text { All first-year full-time students were invited to participate through } \\
\text { email and campus posters with QR codes for electronically } \\
\text { registering for participation by providing university email address. } \\
\text { After verification by university research team of the email addresses } \\
\text { being provided, individual survey links were sent to the students. } \\
\text { Up to } 5 \text { reminder emails, each } 1 \text { week apart, were sent for non- } \\
\text { responding or incomplete surveys. All respondents who completed } \\
\text { surveys were given HKD100 (=USD 12.8) shopping coupons as } \\
\text { incentives. }\end{array}$ \\
\hline
\end{tabular}




5 private/4
Mexico

$\sim 28,000$

10,747

8,076

$75.1 \%$

sessions (1 university), or as part of required classes (3 universities)

All first-year students were eligible for the survey. Initial contact differed by university: survey included in an obligatory health evaluation (2 universities), as part of obligatory group tutoring or teacher evaluations ( 2 universities) and direct invitations from university administrators (1). Two universities sent reminder emails (tutors sent out emails to their tutees; in a required class of personal development, reminders were sent out by faculty). No incentives were applied for baseline surveys.

All first-year students due to register were invited to participate. Following registration, ID numbers and links to the survey were provided. Five reminder emails/text messages were sent with

\section{Northern-}

1 public

$\sim 25,000$

4,359

739

$17.0 \%$

South-

1 public

$\sim 30,000$

5,338

686

$12.9 \%$

personalized links to the survey. A 6th reminder involved a

researcher telephoning non-responders. All responders were entered into a number of draws to win an iPad.

All first-year students were invited to participate through e-mail.

Eight reminder emails and one text message were sent with personalized links to the survey. Conditional incentives were applied (5x R1000 draw).

All first-year students were eligible for the survey. Initial contact differed by university (information stands, information sessions in classrooms, through the university's website). Four reminder emails

Spain $\quad 5$ public $\quad \sim 96,000$

16,332

2,118

$13.0 \%$

2014-15

were sent with personalized links to the survey. Conditional

monetary incentives were applied. Additionally, an end-game strategy was implemented by selecting a random proportion of nonrespondents and offering all of them a monetary incentive.

All first-year students were invited to participate through e-mail.

\section{United}

3 private

4,382

739

$16.9 \%$

2015-16 Three reminder emails were sent with personalized links to the survey. Conditional incentives were applied (gift cards).

\begin{tabular}{ccccccc}
\hline Total & $\begin{array}{c}8 \text { private/ } 16 \\
\text { public }\end{array}$ & $\sim 333,800$ & 79,746 & 21,369 & $45.6 \% *$ & $2014-18$ \\
\hline
\end{tabular}

Note: * weighted by achieved sample size. 


\section{Supplementary Table 2.}

Associations between sociodemographic characteristics and non-suicidal self-injury in the WMH-ICS.

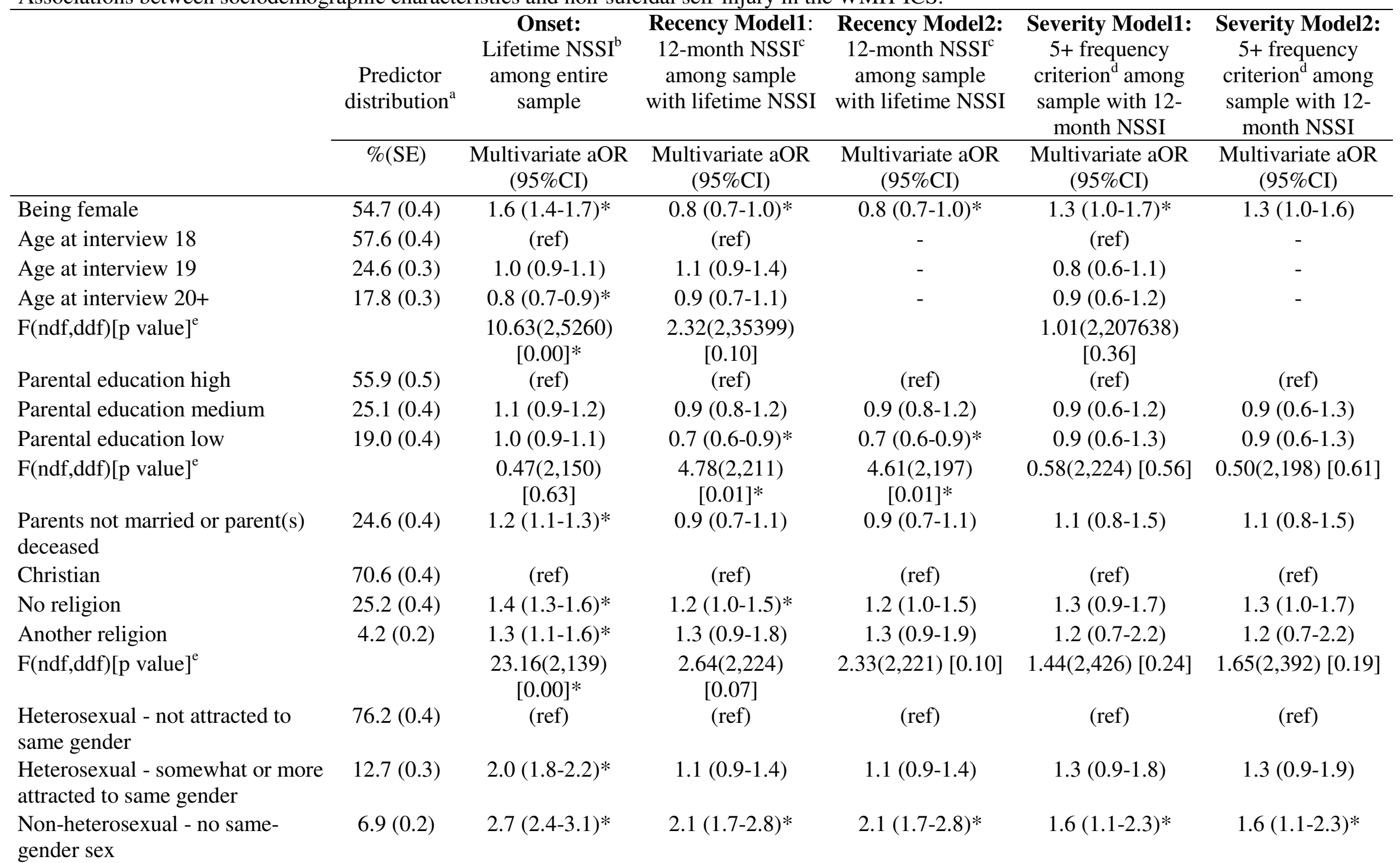




\begin{tabular}{|c|c|c|c|c|c|c|}
\hline $\begin{array}{l}\text { Non-heterosexual and/or same- } \\
\text { gender sex }\end{array}$ & $4.2(0.2)$ & $2.9(2.5-3.3)^{*}$ & $1.7(1.2-2.4)^{*}$ & $1.7(1.2-2.4)^{*}$ & $1.6(1.0-2.5)^{*}$ & $1.6(1.0-2.6)^{*}$ \\
\hline $\begin{array}{l}\text { Self-reported ranking high school } \\
\text { top } 10 \%\end{array}$ & $46.4(0.4)$ & - & (ref) & (ref) & (ref) & (ref) \\
\hline $\begin{array}{l}\text { Self-reported ranking high school } \\
\text { top } 30 \% \text { to } 10 \%\end{array}$ & $29.2(0.4)$ & - & $1.1(0.9-1.3)$ & $1.1(0.9-1.3)$ & $0.9(0.7-1.2)$ & $0.9(0.7-1.2)$ \\
\hline $\begin{array}{l}\text { Self-reported ranking high school } \\
\text { bottom } 70 \%\end{array}$ & $24.4(0.4)$ & - & $1.1(0.9-1.3)$ & $1.1(0.9-1.3)$ & $1.3(0.9-1.8)$ & $1.3(0.9-1.8)$ \\
\hline $\mathrm{F}$ (ndf,ddf) $[\mathrm{p} \text { value }]^{\mathrm{e}}$ & & & $\begin{array}{c}0.30(2,699) \\
{[0.74]}\end{array}$ & $0.29(2,700)[0.75]$ & $2.41(2,289)[0.09]$ & $2.35(2,269)[0.10]$ \\
\hline NSSI onset 11 or younger & $17.9(0.7)$ & - & - & (ref) & - & (ref) \\
\hline NSSI onset ages $12-14$ & $36.5(0.8)$ & - & - & $0.7(0.5-1.0)^{*}$ & - & $0.8(0.5-1.3)$ \\
\hline NSSI onset ages $15-17$ & $37.9(0.8)$ & - & - & $0.6(0.4-0.9)^{*}$ & - & $0.6(0.3-1.1)$ \\
\hline NSSI onset ages 18-19 & $6.6(0.5)$ & - & - & $1.0(0.6-1.7)$ & - & $0.3(0.2-0.8)^{*}$ \\
\hline NSSI onset 6-7 years ago & $18.8(0.7)$ & - & $0.8(0.6-1.0)$ & $1.0(0.7-1.3)$ & $0.5(0.4-0.8)^{*}$ & $0.6(0.4-1.0)^{*}$ \\
\hline NSSI onset 4-5 years ago & $26.6(0.8)$ & - & $0.8(0.7-1.1)$ & $1.1(0.8-1.5)$ & $0.6(0.5-0.9)^{*}$ & $0.9(0.5-1.4)$ \\
\hline NSSI onset 2-3 years ago & $24.9(0.7)$ & - & $1.0(0.8-1.2)$ & $1.5(1.0-2.1)^{*}$ & $0.4(0.3-0.6)^{*}$ & $0.7(0.4-1.2)$ \\
\hline NSSI onset year before college & $9.7(0.5)$ & - & $4.1(2.9-5.6)^{*}$ & $5.0(3.2-7.8)^{*}$ & $0.3(0.2-0.5)^{*}$ & $0.7(0.4-1.5)$ \\
\hline$F(n d f, d d f)[p \text { value }]^{e}$ & & & $\begin{array}{c}28.33(4,64406) \\
{[0.00]^{*}}\end{array}$ & $\begin{array}{c}17.69(4,78378) \\
{[0.00]^{*}}\end{array}$ & $\begin{array}{c}9.07(4,26568) \\
{[0.00]^{*}}\end{array}$ & $\begin{array}{c}1.57(4,57157) \\
{[0.18]}\end{array}$ \\
\hline
\end{tabular}

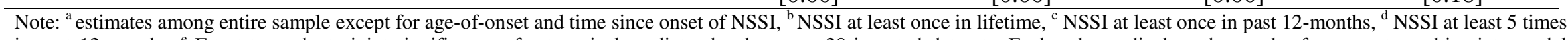
in past 12-months, ${ }^{\mathrm{e}}$ F-test to evaluate joint significance of categorical predictor levels across 20 imputed datasets. Each column displays the result of a separate multivariate model

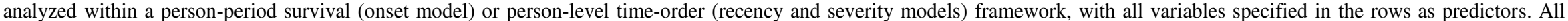
models control country membership and the onset model also controls person-year. Empty cells indicate the predictor specified in the row was not included in the model. The recency and

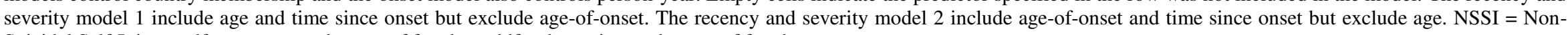
Suicidal Self-Injury, $\mathrm{ndf}=$ numerator degrees of freedom, $\mathrm{ddf}=$ denominator degrees of freedom.

*Significant at the .05 level, two-sided test. 
Supplementary Table 3.

Multivariate associations between temporally prior non-suicidal self-injury and onset of DSM-IV mental disorders in the WMH-ICS.

\begin{tabular}{|c|c|c|c|c|c|c|}
\hline & $\begin{array}{l}\text { Onset Major } \\
\text { depressive } \\
\text { disorder }\end{array}$ & $\begin{array}{c}\text { Onset } \\
\text { Generalized } \\
\text { anxiety } \\
\text { disorder }\end{array}$ & $\begin{array}{l}\text { Onset Panic } \\
\text { disorder }\end{array}$ & $\begin{array}{l}\text { Onset Bipolar } \\
\text { disorder }\end{array}$ & $\begin{array}{c}\text { Onset Alcohol } \\
\text { use disorder }\end{array}$ & $\begin{array}{l}\text { Onset Drug } \\
\text { use disorder }\end{array}$ \\
\hline Temporally prior predictors & $\begin{array}{l}\text { Multivariate } \\
\text { aOR }(95 \% \mathrm{CI})\end{array}$ & $\begin{array}{l}\text { Multivariate } \\
\mathrm{aOR}(95 \% \mathrm{CI})\end{array}$ & $\begin{array}{l}\text { Multivariate } \\
\text { aOR }(95 \% \mathrm{CI})\end{array}$ & $\begin{array}{c}\text { Multivariate } \\
\text { aOR }(95 \% \mathrm{CI})\end{array}$ & $\begin{array}{c}\text { Multivariate } \\
\text { aOR }(95 \% \mathrm{CI})\end{array}$ & $\begin{array}{c}\text { Multivariate } \\
\text { aOR }(95 \% \mathrm{CI})\end{array}$ \\
\hline Non-suicidal self-injury & $1.3(1.1-1.5)^{*}$ & $1.4(1.3-1.6)^{*}$ & $1.7(1.4-2.1)^{*}$ & $2.0(1.6-2.5)^{*}$ & $1.8(1.5-2.3)^{*}$ & $1.8(1.5-2.3)^{*}$ \\
\hline Major depressive disorder & - & $4.0(3.5-4.6)^{*}$ & $3.0(2.3-4.1)^{*}$ & - & $1.3(1.0-1.6)^{*}$ & $2.1(1.5-2.9)^{*}$ \\
\hline Generalized anxiety disorder & $2.8(2.4-3.2)^{*}$ & - & $4.4(3.2-6.0)^{*}$ & $4.6(3.7-5.7)^{*}$ & $1.3(0.9-1.9)$ & $1.3(0.8-2.3)$ \\
\hline Panic disorder & $1.6(1.0-2.4)^{*}$ & $3.9(3.0-5.1)^{*}$ & - & $3.5(2.1-5.9)^{*}$ & $1.7(1.1-2.4)^{*}$ & $1.6(1.1-2.5)^{*}$ \\
\hline Bipolar disorder & - & $3.9(3.1-4.9)^{*}$ & $3.8(2.5-5.8)^{*}$ & - & $2.4(1.8-3.2)^{*}$ & $2.6(1.7-4.0)^{*}$ \\
\hline Alcohol use disorder & $1.4(1.0-2.0)^{*}$ & $2.3(1.7-3.0)^{*}$ & $1.7(1.0-2.9)$ & $3.1(2.0-4.8)^{*}$ & - & $5.0(3.7-6.7)^{*}$ \\
\hline Drug use disorder & $1.3(0.8-2.0)$ & $1.3(0.9-2.0)$ & $1.5(0.8-2.8)$ & $1.9(1.1-3.3)^{*}$ & $2.3(1.6-3.4)^{*}$ & - \\
\hline $\begin{array}{l}\text { Number of temporally prior } \\
\text { mental disorders } \\
\text { None or exactly one mental } \\
\text { disorder }\end{array}$ & (ref) & (ref) & (ref) & (ref) & (ref) & (ref) \\
\hline Two or more mental disorders & $0.4(0.2-0.7)^{*}$ & $0.5(0.3-0.7)^{*}$ & $0.4(0.2-0.5)^{*}$ & $0.5(0.3-0.9)^{*}$ & $0.6(0.4-1.0)$ & $0.7(0.4-1.4)$ \\
\hline
\end{tabular}

ys the result of a separate multivariate model within a person-period survival framework, with temporally prior non-suicidal self-injury and mental disorders in the table as predictors controlling for the following covariates: gender, age, education, marital status parents, religion, sexual orientation, and person-year (not shown here). *Significant at the .05 level, two-sided test. 
Supplementary Table 4.

Multivariate associations between temporally prior non-suicidal self-injury and recency of DSM-IV mental disorders in the WMH-ICS.

\begin{tabular}{|c|c|c|c|c|c|c|}
\hline & $\begin{array}{c}\text { Recency Major } \\
\text { depressive } \\
\text { disorder }\end{array}$ & $\begin{array}{c}\text { Recency } \\
\text { Generalized } \\
\text { anxiety } \\
\text { disorder } \\
\end{array}$ & $\begin{array}{c}\text { Recency } \\
\text { Panic disorder }\end{array}$ & $\begin{array}{l}\text { Recency } \\
\text { Bipolar } \\
\text { disorder }\end{array}$ & $\begin{array}{l}\text { Recency } \\
\text { Alcohol use } \\
\text { disorder }\end{array}$ & $\begin{array}{l}\text { Recency } \\
\text { Drug use } \\
\text { disorder }\end{array}$ \\
\hline Temporally prior predictors & $\begin{array}{c}\text { Multivariate } \\
\text { aOR }(95 \% \mathrm{CI})\end{array}$ & $\begin{array}{c}\text { Multivariate } \\
\text { aOR }(95 \% \mathrm{CI})\end{array}$ & $\begin{array}{c}\text { Multivariate } \\
\text { aOR }(95 \% \mathrm{CI})\end{array}$ & $\begin{array}{c}\text { Multivariate } \\
\text { aOR }(95 \% \mathrm{CI})\end{array}$ & $\begin{array}{c}\text { Multivariate } \\
\text { aOR }(95 \% \mathrm{CI})\end{array}$ & $\begin{array}{c}\text { Multivariate } \\
\text { aOR }(95 \% \mathrm{CI})\end{array}$ \\
\hline Non-suicidal self-injury & $1.1(0.7-1.5)$ & $1.6(1.1-2.3)^{*}$ & $1.1(0.4-2.8)$ & $4.6(1.4-15.4)^{*}$ & $1.2(0.6-2.5)$ & $1.0(0.6-1.8)$ \\
\hline Major depressive disorder & - & $1.0(0.6-1.5)$ & $1.2(0.3-4.4)$ & - & $1.5(0.6-3.7)$ & $1.2(0.6-2.6)$ \\
\hline Generalized anxiety disorder & $1.0(0.7-1.5)$ & . & $1.1(0.3-4.2)$ & $0.9(0.4-2.3)$ & $2.6(0.9-7.3)$ & $1.0(0.5-2.3)$ \\
\hline Panic disorder & $1.8(0.6-5.5)$ & $1.8(0.6-4.8)$ & - & l & $1.2(0.3-5.4)$ & $0.9(0.4-2.4)$ \\
\hline Bipolar disorder & - & $4.9(1.2-19.1)^{*}$ & $2.2(0.3-17.6)$ & - & $1.2(0.5-3.3)$ & $1.6(0.6-4.2)$ \\
\hline Alcohol use disorder & $1.9(0.6-5.9)$ & $0.9(0.3-2.9)$ & l & $1.1(0.2-6.1)$ & - & $1.8(0.9-3.4)$ \\
\hline Drug use disorder & $1.3(0.4-4.2)$ & $1.6(0.4-7.4)$ & $0.8(0.1-5.0)$ & $0.3(0.0-3.6)$ & $0.5(0.2-1.4)$ & - \\
\hline
\end{tabular}

\section{Number of temporally prior}

\section{mental disorders}

None or exactly one menta disorder

: Each column displays the result of a separate multivariate model within a person-level time-order framework, with temporally prior non-suicidal self-injury and mental disorders in the table as predictors controlling for the following covariates: gender, age, education, marital status parents, religion, sexual orientation, and high-school ranking (except for panic disorder as the model did not converge), age-of-onset, and time since onset (not shown here). / effect could not be estimated.

*Significant at the .05 level, two-sided test. 